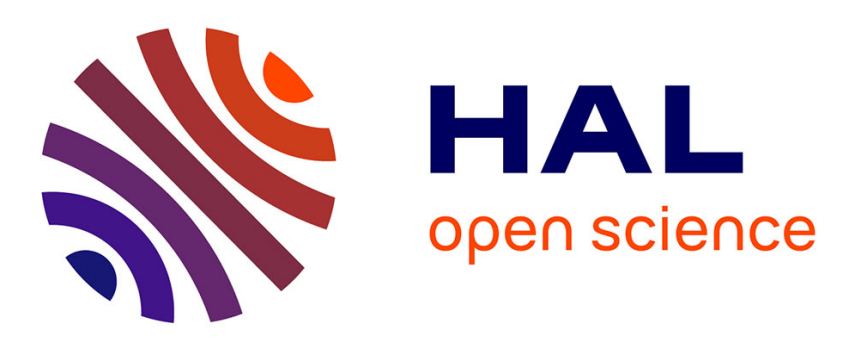

\title{
Cytotoxic prenylated flavonoids from the leaves of Macaranga indica
}

\author{
Doan Thi Mai Huong, Le Tran Nguyen Vu, Luu The Anh, Nguyen Thi Cuc, \\ Nguyen Xuan Nhiem, Bui Huu Tai, Phan van Kiem, Marc Litaudon, Tran \\ Dang Thach, Chau van Minh, et al.
}

\section{To cite this version:}

Doan Thi Mai Huong, Le Tran Nguyen Vu, Luu The Anh, Nguyen Thi Cuc, Nguyen Xuan Nhiem, et al.. Cytotoxic prenylated flavonoids from the leaves of Macaranga indica. Phytochemistry Letters, 2019, 34, pp.39 - 42. 10.1016/j.phytol.2019.09.001 . hal-03353444

\author{
HAL Id: hal-03353444 \\ https://hal.science/hal-03353444
}

Submitted on 24 Sep 2021

HAL is a multi-disciplinary open access archive for the deposit and dissemination of scientific research documents, whether they are published or not. The documents may come from teaching and research institutions in France or abroad, or from public or private research centers.
L'archive ouverte pluridisciplinaire HAL, est destinée au dépôt et à la diffusion de documents scientifiques de niveau recherche, publiés ou non, émanant des établissements d'enseignement et de recherche français ou étrangers, des laboratoires publics ou privés. 


\section{Manuscript Details}

Manuscript number

Title

Short title

Article type
PHYTOL_2019_300

Cytotoxic prenylated flavonoids from the leaves of Macaranga indica

Prenylated flavonoids from Macaranga indica

Short Communication

\section{Abstract}

Three new prenylated flavonoids, macarindicins D-F (1-3) together with eight known compounds, macadenathin B (4), glyasperin A (5), kaempferol (6), quercetin (7), quercitrin (8), (+)-isolariciresinol (9), (-)-woonenoside XI (10), and (+)lyoniresinol 4-O- $\beta$-D-glucopyranoside (11) were isolated from the leaves of Macaranga indica Wight. Their structures were determined on the basis of extensive spectroscopic methods, including 1D-, 2D-NMR and MS data. All the isolated compounds were tested for their cytotoxic activities against KB, MCF-7, HepG-2, and LU human cancer cell lines. As results, compound 2 showed significant cytotoxic activity on all human cancer cell lines with IC50 values ranging from 11.0 to $17.0 \mu \mathrm{M}$. Compound 3-5, exhibited moderate cytotoxic activity against four cancer cell lines with an IC50 values ranging from 15.0 to $38.2 \mu \mathrm{M}$.

\section{Keywords}

Taxonomy

Corresponding Author

Order of Authors

Suggested reviewers
Macaranga indica; macarindicin D; macarindicin E; macarindicin F; cytotoxic

Molecular Structure, Natural Product Biochemistry

Van Cuong Pham

Van Cuong Pham, Doan Thi Mai Huong, Le Tran Nguyen Vu, Luu The Anh, Nguyen Thi Cuc, Nhiem Nguyen, Bui Huu Tai, Phan Van Kiem, Marc Litaudon, Dang Tran Thach, Minh Chau Van

Seung Hyun Kim, Tran Minh Ngoc, Tuyen Nguyen Van

\section{Submission Files Included in this PDF}

\section{File Name [File Type]}

Phytochemistry Letterrs cover letter.doc [Cover Letter]

Phytochem lett Highlights.doc [Highlights]

Phytochem lett Graphical abstract.docx [Graphical Abstract]

Phytochemistry Letters Macaranga indica.docx [Manuscript File]

Supporting information Macaranga indica.doc [Figure]

To view all the submission files, including those not included in the PDF, click on the manuscript title on your EVISE Homepage, then click 'Download zip file'.

\section{Research Data Related to this Submission}

There are no linked research data sets for this submission. The following reason is given:

No data was used for the research described in the article 


\section{Highlights}

\section{Cytotoxic prenylated flavonoids from the leaves of Macaranga indica}

Doan Thi Mai Huong, Le Tran Nguyen Vu, Luu The Anh, Nguyen Thi Cuc, Nguyen Xuan Nhiem, Bui Huu Tai, Phan Van Kiem, Marc Litaudon, Tran Dang Thach, Chau Van Minh, and Pham Van Cuong*

- Three new prenylated flavonoids were isolated from Macaranga indica.

- The structures were successfully determined by spectroscopic evidence.

- Comp. 2 showed significant activity on tested cancer cells $\left(\mathrm{IC}_{50}\right.$ ranging 11.0 17.0 $\left.\mu \mathrm{M}\right)$. 


\section{Graphical abstract}

\section{Cytotoxic prenylated flavonoids from the leaves of Macaranga indica}

Doan Thi Mai Huong, Le Tran Nguyen Vu, Luu The Anh, Nguyen Thi Cuc, Nguyen Xuan Nhiem, Bui Huu Tai, Phan Van Kiem, Marc Litaudon, Tran Dang Thach, Chau Van Minh, and Pham Van Cuong*

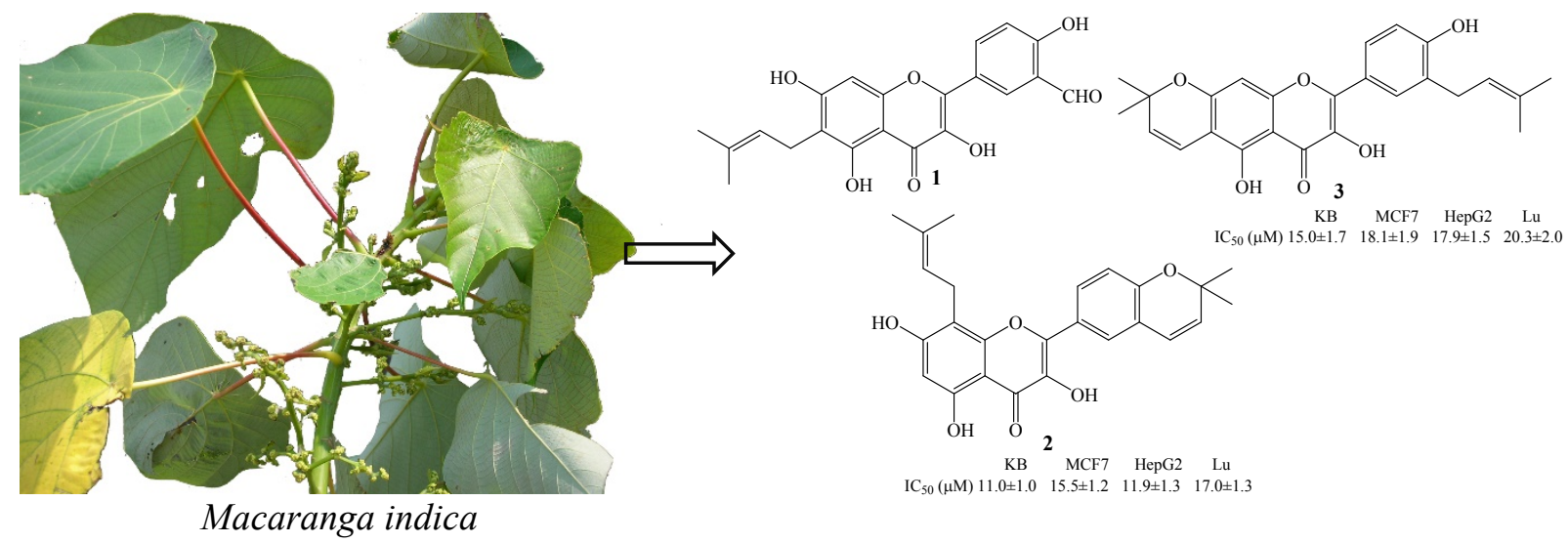




\section{Cytotoxic prenylated flavonoids from the leaves of Macaranga indica}

Doan Thi Mai Huong ${ }^{\mathrm{a}, \mathrm{c}}$, Le Tran Nguyen Vuª,c), Luu The Anh ${ }^{\mathrm{b})}$, Nguyen Thi Cuc ${ }^{\mathrm{a}, \mathrm{c})}$, Nguyen Xuan Nhiem ${ }^{\mathrm{a}, \mathrm{c}}$, Bui Huu Tai ${ }^{\mathrm{a}, \mathrm{c}}$, Phan Van Kiem, ${ }^{\mathrm{a}, \mathrm{c}}$, Marc Litaudon ${ }^{\mathrm{d})}$, Tran Dang Thache, Chau Van Minha), and Pham Van Cuong a,c*

a) Advanced Center for Bioorganic Chemistry, Institute of Marine Biochemistry (IMBC), Vietnam Academy of Science and Technology (VAST), 18 Hoang Quoc Viet, Cau Giay, Hanoi, Vietnam

${ }^{b)}$ Central Institute for Natural Resources and Environmental Studies, Vietnam National National University, Hanoi, 19 Le Thanh Tong, Hoan Kiem, Hanoi, Vietnam

${ }^{c}$ Graduate University of Science and Technology, VAST, 18 Hoang Quoc Viet, Caugiay, Hanoi, Vietnam

d)Institut de Chimie des Substances Naturelles, CNRS-ICSN, UPR 2301,_Université ParisSaclay, 91198, Gif-sur-Yvette, France

e) Institute of Applied Science and Technology, University Industry Vinh, Vinh, Vietnam

Corresponding author

\section{Pham Van Cuong, Prof, Ph.D.}

Advanced Center for Bioorganic Chemistry, Institute of Marine Biochemistry (IMBC), Vietnam Academy of Science and Technology (VAST), 18 Hoang Quoc Viet, Cau Giay, Hanoi, Vietnam

E-mail address: phamvc@imbc.vast.vn 


\begin{abstract}
Three new prenylated flavonoids, macarindicins D-F (1-3) together with eight known compounds, macadenathin B (4), glyasperin A (5), kaempferol (6), quercetin (7), quercitrin (8), (+)-isolariciresinol (9), (-)-woonenoside $\quad \mathrm{XI} \quad(\mathbf{1 0}), \quad$ and $\quad(+)$-lyoniresinol $4-O-\beta-\mathrm{D}-$ glucopyranoside (11) were isolated from the leaves of Macaranga indica Wight. Their structures were determined on the basis of extensive spectroscopic methods, including 1D-, 2DNMR and MS data. All the isolated compounds were tested for their cytotoxic activities against KB, MCF-7, HepG-2, and LU human cancer cell lines. As results, compound 2 showed significant cytotoxic activity on all human cancer cell lines with $\mathrm{IC}_{50}$ values ranging from 11.0 to $17.0 \mu \mathrm{M}$. Compound $\mathbf{3 - 5}$, exhibited moderate cytotoxic activity against four cancer cell lines with an $\mathrm{IC}_{50}$ values ranging from 15.0 to $38.2 \mu \mathrm{M}$.
\end{abstract}

Keywords: Macaranga indica; macarindicin D; macarindicin E; macarindicin F; cytotoxic 


\section{Introduction}

Prenylated flavonoids play important roles in the plant's defensive strategy. Recently, the research on prenylated flavonoids have received the attention from the scientists due to their promising and diverse bioactivities on multitarget tissues. Prenylated flavonoids showed potential cytotoxic activity against tumor and cancer cell lines (Chen et al. 2014).

The genus Macaranga (Euphorbiaceae) comprises of about 300 species which are mainly distributed in tropics of Africa, Asia, Australia, and the Pacific regions. The Macaranga genus have been used in traditional medicine for the treatments of cuts, swellings, boils, bruises, and sores. Phytochemical investigation of this genus confirmed the presence of stilbenes, flavonoids, coumarins, terpenoids, and tannins (Magadula 2014). The extracts and those compounds showed a wide spectrum of pharmacological activities including anti-cancer, anti-inflammatory, anti-oxidant, anti-microbial, and anti-plasmodial activities. Previous phytochemical investigations of $M$. indica led to the isolation and identification of flavonoids and prenylated derivatives (Yang et al. 2015a). As part of our research on anticancer drug candidates from 2,500 Vietnamese medicinal plants, the ethyl acetate extract of $M$. indica was found to inhibit $69 \%$ the growth of KB human cancer cell line at the concentration of $1.0 \mu \mathrm{g} / \mathrm{ml}$. Herein, we report the isolation and structure elucidation of three new prenylated flavonoids together with eight known compounds from $M$. indica and evaluation of their cytotoxic effects.

\section{Results and discussion}

Compound 1 was obtained as a yellow amorphous powder. Its molecular formula was defined as $\mathrm{C}_{21} \mathrm{H}_{18} \mathrm{O}_{7}$ by HR-ESI-MS at $m / z 383.1125[\mathrm{M}+\mathrm{H}]^{+}\left(\right.$Calcd. for $\left[\mathrm{C}_{21} \mathrm{H}_{19} \mathrm{O}_{7}\right]^{+}, 383.1131$ ). The ${ }^{1} \mathrm{H}-\mathrm{NMR}$ spectrum of $\mathbf{1}$ showed the signals of three aromatic protons with ABX system of B ring at $\delta_{\mathrm{H}} 7.18(1 \mathrm{H}, \mathrm{d}, J=9.0 \mathrm{~Hz}), 8.29(1 \mathrm{H}, \mathrm{dd}, J=2.0,9.0 \mathrm{~Hz})$, and $8.50(1 \mathrm{H}, \mathrm{d}, J=2.0 \mathrm{~Hz})$; one aromatic proton of A ring at $\delta_{\mathrm{H}} 6.50(1 \mathrm{H}, \mathrm{s})$ suggested the presence of flavonol moiety; one 
olefinic proton at $\delta_{\mathrm{H}} 5.19(1 \mathrm{H}, \mathrm{t}, J=7.0 \mathrm{~Hz})$ and two methyl groups at $\delta_{\mathrm{H}} 1.63(3 \mathrm{H}, \mathrm{s})$ and 1.73 $(3 \mathrm{H}, \mathrm{s})$ suggested the presence of a prenyl group; and one aldehydic proton at $\delta_{\mathrm{H}} 10.35(1 \mathrm{H}, \mathrm{s})$. The ${ }^{13} \mathrm{C}-\mathrm{NMR}$ and HSQC spectra (Table 1) of 1 showed the signals of 21 carbons, including one carbonyl carbon $\left(\delta_{\mathrm{C}} 175.9\right)$, one aldehydic carbon $\left(\delta_{\mathrm{C}} 190.5\right)$, eleven non-protonateds $\left(\delta_{\mathrm{C}}\right.$ $102.8,110.3,122.3 \times 2,130.6,136.2,145.0,154.0,157.4,161.7$, and 161.8$)$, five methines $\left(\delta_{\mathrm{C}}\right.$ $92.7,117.7,122.1,128.3$, and 134.9) one methylene $\left(\delta_{\mathrm{C}} 20.9\right)$, and two methyl carbons at $\left(\delta_{\mathrm{C}}\right.$ 17.6 and 25.4). Analysis of the ${ }^{1} \mathrm{H}$ - and ${ }^{13} \mathrm{C}-\mathrm{NMR}$ data of $\mathbf{1}$ suggested the structure 1 was a prenylated flavone, similar to those of glyasperin A (5) (Nomura et al. 1992), except for the disappearance of isoprenyl group at $\mathrm{C}-3^{\prime}$ of $\mathrm{B}$ ring. This could be oxidation of prenyl group to form aldehydic group. The positions of the functional groups were confirmed by analysis of the HSQC and HMBC spectra (Figure 2). The HMBC correlations between H-5' $\left(\delta_{\mathrm{H}} 7.18\right)$ and C$1^{\prime}\left(\delta_{\mathrm{C}} 122.3\right) / \mathrm{C}-3^{\prime}\left(\delta_{\mathrm{C}} 122.3\right)$; between H-6' $\left(\delta_{\mathrm{H}} 8.29\right)$ and C-2' $\left(\delta_{\mathrm{C}} 128.3\right) / \mathrm{C}-4^{\prime}\left(\delta_{\mathrm{C}} 161.8\right) / \mathrm{C}-2$ $\left(\delta_{\mathrm{C}} 145.0\right)$; between aldehydic proton $\left(\delta_{\mathrm{H}} 10.35\right)$ and C-2' $\left(\delta_{\mathrm{C}} 128.3\right) / \mathrm{C}-3^{\prime}\left(\delta_{\mathrm{C}} 122.3\right) / \mathrm{C}-4^{\prime}\left(\delta_{\mathrm{C}}\right.$ 161.8) suggested the positions of hydroxy group at C-4' and the aldehydic group at C-3'. The HMBC correlations between $\mathrm{H}-8\left(\delta_{\mathrm{H}} 6.50\right)$ and C-6 $\left(\delta_{\mathrm{C}} 110.3\right) / \mathrm{C}-7\left(\delta_{\mathrm{C}} 161.7\right) / \mathrm{C}-9\left(\delta_{\mathrm{C}} 154.0\right) / \mathrm{C}-$ $10\left(\delta_{\mathrm{C}} 102.8\right)$; between H-1" $\left(\delta_{\mathrm{H}} 3.24\right)$ and C-5 $\left(\delta_{\mathrm{C}} 157.4\right) / \mathrm{C}-6\left(\delta_{\mathrm{C}} 110.3\right) / \mathrm{C}-7\left(\delta_{\mathrm{C}} 161.7\right)$ suggested the position of prenyl group at C-6 and the hydroxy groups at C-5 and C-7. Thus, the structure of 1 was determined and named macarindicin D.

Macarindicin E (2) possessed a molecular formula of $\mathrm{C}_{25} \mathrm{H}_{24} \mathrm{O}_{6}$ as deduced from HR-ESI-MS at $m / z 421.1642[\mathrm{M}+\mathrm{H}]^{+}\left(\right.$Calcd. for $\left.\left[\mathrm{C}_{25} \mathrm{H}_{25} \mathrm{O}_{6}\right]^{+}, 421.1651\right)$. The ${ }^{1} \mathrm{H}-\mathrm{NMR}$ spectrum of 2 showed the following signals: three $\mathrm{ABX}$ aromatic protons of $\mathrm{B}$ ring at $\delta_{\mathrm{H}} 6.92(1 \mathrm{H}, \mathrm{d}, J=9.0$ $\mathrm{Hz}), 7.85(1 \mathrm{H}, \mathrm{d}, J=2.5 \mathrm{~Hz})$, and $7.93(1 \mathrm{H}, \mathrm{dd}, J=2.5,9.0 \mathrm{~Hz})$; one aromatic proton of A ring at $\delta_{\mathrm{H}} 6.30(1 \mathrm{H}, \mathrm{s})$ assigned the presence of flavonol moiety; three olefinic protons $\delta_{\mathrm{H}} 5.17(1 \mathrm{H}$, $\mathrm{t}, J=6.5 \mathrm{~Hz}), 5.85(1 \mathrm{H}, \mathrm{t}, J=10.0 \mathrm{~Hz})$, and $6.46(1 \mathrm{H}, \mathrm{t}, J=10.0 \mathrm{~Hz})$; four methyl groups at $\delta_{\mathrm{H}}$ $1.62(3 \mathrm{H}, \mathrm{s}), 1.74(3 \mathrm{H}, \mathrm{s}), 1.42(6 \mathrm{H}, \mathrm{s})$ suggested the appearance of two prenyl groups. The ${ }^{13} \mathrm{C}-$ 
NMR and HSQC spectra of 2 showed the signals of 25 carbons, including one carbonyl, twelve non-protonateds, seven methines, one methylene, and four methyl carbons. The anaylsis of ${ }^{1} \mathrm{H}-$ and ${ }^{13} \mathrm{C}-\mathrm{NMR}$ data indicated the strucuture of 2 was similar to those of macadenathin $\mathrm{B}$ (4) (Yang et al. 2015b), excepted for the change of prenyl group at A ring. The HMBC correlations between H-6 $\left(\delta_{\mathrm{H}} 6.30\right)$ and C-5 $\left(\delta_{\mathrm{C}} 158.2\right) / \mathrm{C}-7\left(\delta_{\mathrm{C}} 161.2\right) / \mathrm{C}-8\left(\delta_{\mathrm{C}} 105.6\right) / \mathrm{C}-10\left(\delta_{\mathrm{C}} 103.0\right)$; between H-1" $\left(\delta_{\mathrm{H}} 3.43\right)$ and C-7 $\left(\delta_{\mathrm{C}} 161.2\right) / \mathrm{C}-8\left(\delta_{\mathrm{C}} 105.6\right) / \mathrm{C}-9\left(\delta_{\mathrm{C}} 153.4\right)$ suggested the position of prenyl group at C-8. The HMBC correlations between $\mathrm{H}-5^{\prime}\left(\delta_{\mathrm{H}} 6.92\right)$ and $\mathrm{C}-1^{\prime}\left(\delta_{\mathrm{C}} 123.7\right) / \mathrm{C}-3^{\prime}$ $\left(\delta_{\mathrm{C}} 120.6\right)$; between $\mathrm{H}-6^{\prime}\left(\delta_{\mathrm{H}} 7.93\right)$ and C-2 $\left(\delta_{\mathrm{C}} 146.0\right) / \mathrm{C}-2^{\prime}\left(\delta_{\mathrm{C}} 125.6\right) / \mathrm{C}-4^{\prime}\left(\delta_{\mathrm{C}} 153.9\right)$; between $\mathrm{H}-6^{\prime \prime}\left(\delta_{\mathrm{H}} 6.46\right)$ and $\mathrm{C}-2^{\prime}\left(\delta_{\mathrm{C}} 125.6\right) / \mathrm{C}-3^{\prime}\left(\delta_{\mathrm{C}} 120.6\right) \mathrm{C}-4^{\prime}\left(\delta_{\mathrm{C}} 153.9\right) / \mathrm{C}-8^{\prime \prime}\left(\delta_{\mathrm{C}} 77.0\right)$ suggested the position second prenyl group at C-3'. The cyclization of prenyl group with B ring of flavonol via oxy-bridge at C-4' and C- $8^{\prime \prime}$ was confirmed by the shift to low field of C-8" $\left(\delta_{\mathrm{C}} 77.0\right)$ as well as HR-ESI-MS. Based on the above evidence, the structure of $\mathbf{2}$ was determined and named macarindicin E.

Compounds 3 was also obtained as yellow amorphous powders. HR-ESI-MS experiments resulted in the same molecular formula as that of 2 (see Experimental). The ${ }^{1} \mathrm{H}-$ and ${ }^{13} \mathrm{C}-\mathrm{NMR}$ data were almost the same to those of macarindicin E (2), suggesting the possibilities exchange of pyran ring and prenyl positions. The HMBC correlations between $\mathrm{H}-8\left(\delta_{\mathrm{H}} 6.51\right)$ and $\mathrm{C}-6\left(\delta_{\mathrm{C}}\right.$ $103.9) / \mathrm{C}-7\left(\delta_{\mathrm{C}} 158.3\right) / \mathrm{C}-9\left(\delta_{\mathrm{C}} 155.1\right) / \mathrm{C}-10\left(\delta_{\mathrm{C}} 103.9\right) ; \mathrm{H}-4 "\left(\delta_{\mathrm{H}} 1.43\right) / \mathrm{H}-5^{\prime \prime}\left(\delta_{\mathrm{H}} 1.43\right)$ and C$2^{\prime \prime}\left(\delta_{\mathrm{C}} 128.8\right) / \mathrm{C}-3^{\prime \prime}\left(\delta_{\mathrm{C}} 77.8\right)$; and between H-1" $\left(\delta_{\mathrm{H}} 6.61\right)$ and C-5 $\left(\delta_{\mathrm{C}} 154.6\right) / \mathrm{C}-6\left(\delta_{\mathrm{C}} 103.9\right) / \mathrm{C}-7$ $\left(\delta_{\mathrm{C}} 158.3\right)$ suggested the cyclization of prenyl group with flavonol (pyran ring) at C-7 and C$3^{\prime \prime}$. In addition, the presnce of prenyl at C-3' was confirmed by HMBC correlations from $\mathrm{H}-9^{\prime \prime}$ $\left(\delta_{\mathrm{H}} 1.70\right) / \mathrm{H}-10^{\prime \prime}\left(\delta_{\mathrm{H}} 1.70\right)$ to $\mathrm{C}-7^{\prime \prime}\left(\delta_{\mathrm{C}} 122.3\right) / \mathrm{C}-8^{\prime \prime}\left(\delta_{\mathrm{C}} 131.7\right)$; from $\mathrm{H}-6^{\prime \prime}\left(\delta_{\mathrm{H}} 3.28\right)$ to $\mathrm{C}-2^{\prime}\left(\delta_{\mathrm{C}}\right.$ $129.2) / \mathrm{C}-3^{\prime}\left(\delta_{\mathrm{C}} 127.7\right) / \mathrm{C}-4^{\prime}\left(\delta_{\mathrm{C}} 157.0\right)$. Consequently, the structure of $\mathbf{3}$ was determined and named macarindicin F.

The known compounds, macadenathin B (4) (Yang et al. 2015b), glyasperin A (5) (Nomura et 
al. 1992), kaempferol (6), quercetin (7), quercitrin (8) (Nhiem et al. 2011), (+)-isolariciresinol (9) (Jutiviboonsuk et al. 2005), (-)-woonenoside XI (10) (Niwa et al. 2004), and (+)lyoniresinol 4-O- $\beta$-D-glucopyranoside (11) (Buske et al. 2001) were identified by comparison of their NMR data with those reported in the literature.

Compounds 1-11 were evaluated for cytotoxic activity against KB, MCF-7, HepG-2, and LU human cancer cell lines (Table 2). As results, compound $\mathbf{2}$ showed significant cytotoxic activity on all human cancer cell lines with $\mathrm{IC}_{50}$ values ranging from 11.0 to $17.0 \mu \mathrm{M}$, compared to those of positive control, mitoxantrol. Compound 3-5, exhibited moderate cytotoxic activity against four cancer cell lines with $\mathrm{IC}_{50}$ values ranging from 15.0 to $38.2 \mu \mathrm{M}$. Compounds 6-11 did not show cytotoxic activity $\left(\mathrm{IC}_{50}>100 \mu \mathrm{M}\right)$. In the structure-activity relationship, prenylated flavonoids with pyran ring at A or B ring of flavonol (2-4) of showed stronger cytotoxic activity than prenylated derivatives (1 and $\mathbf{5})$ as well as remaining flavonoids (6-8). Recent reports have shown significant cytotoxic effects of prenylated flavonoids (Chen et al. 2014). Flavonoids have the potential of modulating many biological events in cancer such as apoptosis, vascularization, cell differentiation, cell proliferation, etc (Lopez-Lazaro 2002). These results suggest that discovery of prenylated flavonoids may increase the possibility of finding new anticancer agents. The mechanism of action of the $\mathbf{2}$ from this plant or other sources need to be further studied.

\section{Experimental}

\subsection{General experimental procedures}

All NMR spectra were recorded on a Bruker 500 MHz. HR-ESI-MS spectra were obtained using an AGILENT 6550 iFunnel Q-TOF LC/MS system. Column chromatography (CC) was performed on silica-gel (Kieselgel 60, 70-230 mesh and 230-400 mesh, Merck) or RP-18 resins (30 - $50 \mu \mathrm{m}$, Fuji Silysia Chemical Ltd.). For thin layer chromatography (TLC), pre-coated 
silica-gel 60 F254 (0.25 mm, Merck) and RP-18 F254S (0.25 mm, Merck) plates were used.

\subsection{Plant material}

The leaves of Macaranga indica Wight were collected at Huong Hoa, Quangtri, Vietnam in August 2010 and identified by Dr. Nguyen The Cuong, Institute of Ecology and Biological Resources, VAST. A voucher specimen (MI1008) was deposited at the Institute of Marine Biochemistry, VAST.

\subsection{Extraction and isolation}

The dried leaves of $M$. indica $(1.92 \mathrm{~kg})$ were sonicated with hot $\mathrm{MeOH}$ three times $(3 \times 6 \mathrm{~L})$ to yield $155 \mathrm{~g}$ extract after evaporation of the solvent. This extract was suspended in $\mathrm{H}_{2} \mathrm{O}$ and successively partitioned with $\mathrm{CH}_{2} \mathrm{Cl}_{2}$ and EtOAc to obtain the $\mathrm{CH}_{2} \mathrm{Cl}_{2}(\mathrm{MI} 1,88.0 \mathrm{~g})$, EtOAc (MI2, $16.0 \mathrm{~g}$ ), and $\mathrm{H}_{2} \mathrm{O}$ (MI3) extracts after removal of the solvents in vacuo.

The MI1 fraction was chromatographed on a silica gel column eluting with a gradient solvent of $\mathrm{CH}_{2} \mathrm{Cl}_{2} / \mathrm{MeOH}(100: 0 \rightarrow 2.5 / 1, \mathrm{v} / \mathrm{v})$ to give five fractions, MI1A-MIE. MI1B was chromatographed on an RP-18 column eluting with acetone/water $(2.5 / 1, \mathrm{v} / \mathrm{v})$ to give four fractions, MI1B1-MI1B4. MI1B1 was chromatographed on a silica gel column eluting with $n$ hexane/EtOAc (5/1, v/v) to give two fractions, MI1B1A-MI1B1B. Compounds 3 (7.0 mg) and $3(35.0 \mathrm{mg})$ were obtained from MI1B1B on a silica gel column eluting with $n$-hexane/acetone (3/1, v/v). MI1B2 was chromatographed on a silica gel column eluting with $\mathrm{CH}_{2} \mathrm{Cl}_{2} / \mathrm{MeOH}$ $(60 / 1, \mathrm{v} / \mathrm{v})$ to give three smaller fractions, MI1B2A-MI1B2C. Compound 1 (12.0 mg) was obtained from MI1B2B on a silica gel column, using $n$-hexane/EtOAc (3/1, v/v) as eluent solvents. MI1B2C was chromatographed on a silica gel column eluting with $n$-hexane/EtOAc $(3 / 1, \mathrm{v} / \mathrm{v})$ to yield compound $2(10.0 \mathrm{mg})$. MI1B4 was chromatographed on a silica gel column eluting with $\mathrm{CH}_{2} \mathrm{Cl}_{2} / \mathrm{EtOAc}(20 / 1, \mathrm{v} / \mathrm{v})$ to give two fractions, MI1B4A-MI1B4B. MI1B4A was chromatographed on a sephadex LH-20 column eluting with $\mathrm{MeOH} /$ water $(1 / 1, \mathrm{v} / \mathrm{v})$ to yield compound 5 (70.0 mg). The MI1D was chromatographed on silica gel column eluting with $n$ - 
hexane/acetone $(2 / 1, \mathrm{v} / \mathrm{v})$ to give four fractions, MI1D1-MI1D4. MI1D3 was chromatographed on a silica gel column eluting with $n$-hexane/EtOAc $(1 / 1, \mathrm{v} / \mathrm{v})$ to give two smaller fractions, MI1D3A-MI1D3B. MI1D3A was chromatographed on a Sephadex LH-20 column eluting with $\mathrm{MeOH} /$ water $(1 / 1, \mathrm{v} / \mathrm{v})$ to yield compound $9(6.0 \mathrm{mg})$. MI1E was chromatographed on a RP-18 column eluting with acetone/water $(2 / 1, \mathrm{v} / \mathrm{v})$ to give three fractions, MIE1-MI1E3. MIE2 was chromatographed on a silica gel column eluting with $\mathrm{CH}_{2} \mathrm{Cl}_{2} / \mathrm{MeOH}(5 / 1, \mathrm{v} / \mathrm{v})$ to give two fractions, MI1E2A-MI1E2B. MI1E2A was chromatographed on a sephadex LH-20 column eluting with $\mathrm{MeOH} /$ water $(1 / 1, \mathrm{v} / \mathrm{v})$ to yield compound $8(9.0 \mathrm{mg})$.

The MI2 fraction was chromatographed on a silica gel column eluting with a gradient of $\mathrm{CH}_{2} \mathrm{Cl}_{2} / \mathrm{MeOH}(40 / 1 \rightarrow 1 / 1, \mathrm{v} / \mathrm{v})$ to give four fractions, MI2A-MI2D. MI2A was chromatographed on a RP-18 column eluting with $\mathrm{MeOH} /$ water $(1.5 / 1, \mathrm{v} / \mathrm{v})$ to give two smaller fractions, MI2A1-MI2A2. MI2A1 was chromatographed on a sephadex LH-20 column eluting with $\mathrm{MeOH} /$ water $(1 / 1, \mathrm{v} / \mathrm{v})$ to yield compound 7 (40.0 mg). Compound 6 (35.0 mg) was obtained from MI2A2 on a silica gel column using $\mathrm{CH}_{2} \mathrm{Cl}_{2} / \mathrm{MeOH}(10 / 1, \mathrm{v} / \mathrm{v})$ as eluent solvents. The MI3 was chromatographed on a Diaion HP-20 column first eluting with water to remove sugar components, then increasing concentration of $\mathrm{MeOH}$ in water $(25,50,75$, and $100 \%$ of $\mathrm{MeOH}$ ) to obtain four fractions, MI3A-MI3D. The MI3B fractions were chromatographed on a silica gel column eluting with a gradient of $\mathrm{CH}_{2} \mathrm{Cl}_{2} / \mathrm{MeOH}(10 / 1 \rightarrow 0 / 1)$ to give four fractions, MI3B1-MI3B4. MI3B1 was chromatographed on a RP-18 column eluting with $\mathrm{MeOH} /$ water $(1 / 2, v / v)$ to give three fractions, MI3B1A-MI3B1C. MI3B1A was chromatographed on a silica gel column eluting with $\mathrm{CH}_{2} \mathrm{Cl}_{2} / \mathrm{MeOH}(5 / 1, \mathrm{v} / \mathrm{v})$ to yield compounds $10(8.0 \mathrm{mg})$ and $11(12.0$ $\mathrm{mg})$.

\subsubsection{Macarindicin A (1)}

Yellow amorphous powder. HR-ESI-MS m/z: $383.1125[\mathrm{M}+\mathrm{H}]^{+}\left(\mathrm{Calcd}\right.$. for $\left[\mathrm{C}_{21} \mathrm{H}_{19} \mathrm{O}_{7}\right]^{+}$, 383.1131). ${ }^{1} \mathrm{H}-\mathrm{NMR}$ (DMSO-d 6 , $500 \mathrm{MHz}$ ) and ${ }^{13} \mathrm{C}-\mathrm{NMR}$ (DMSO-d 6 , $125 \mathrm{MHz}$ ): see Table 1.

\subsubsection{Macarindicin B (2)}


Yellow amorphous powder. HR-ESI-MS m/z: $421.1642[\mathrm{M}+\mathrm{H}]^{+}\left(\right.$Calcd. for $\left[\mathrm{C}_{25} \mathrm{H}_{25} \mathrm{O}_{6}\right]^{+}$, 421.1651). ${ }^{1} \mathrm{H}-\mathrm{NMR}$ (DMSO-d 6 , $500 \mathrm{MHz}$ ) and ${ }^{13} \mathrm{C}-\mathrm{NMR}$ (DMSO-d 6 , $125 \mathrm{MHz}$ ): see Table 1.

\subsubsection{Macarindicin C (3)}

Yellow amorphous powder. HR-ESI-MS m/z: $421.1642[\mathrm{M}+\mathrm{H}]^{+}\left(\right.$Calcd. for $\left[\mathrm{C}_{25} \mathrm{H}_{25} \mathrm{O}_{6}\right]^{+}$, 421.1651). ${ }^{1} \mathrm{H}-\mathrm{NMR}$ (DMSO-d ${ }_{6}, 500 \mathrm{MHz}$ ) and ${ }^{13} \mathrm{C}-\mathrm{NMR}$ (DMSO-d 6 , $125 \mathrm{MHz}$ ): see Table 1.

3.4. Cytotoxic assays: See reference (Thu et al. 2015)

\section{Acknowledgment}

The Centre National de la Recherche Scientifique (CNRS, France) is gratefully acknowledged for the Franco-Vietnamese Cooperation Program and The Ministry of Science and Technology of Vietnam for financial support [Grant number ĐTĐLCN.14/16].

\section{Appendix A. Supplementary data}

Supplementary material associated with this article can be found, in the online version, at sciencedirect.com. 


\section{References}

1. Buske A., Schmidt J., Porzel A., Adam G., 2001. Alkaloidal, Megastigmane and Lignan Glucosides from Antidesma membranaceum (Euphorbiaceae). European Journal of Organic Chemistry 2001, 3537-3543.

2. Chen X., Mukwaya E., Wong M.-S., Zhang Y., 2014. A systematic review on biological activities of prenylated flavonoids. Pharm. Biol. 52, 655-660.

3. Jutiviboonsuk A., Zhang H., Tan G.T., Ma C., Hung N.V., Cuong N.M., Bunyapraphatsara N., Soejarto D.D., Fong H.H.S., 2005. Bioactive constituents from roots of Bursera tonkinensis. Phytochemistry 66, 2745-2751.

4. Lopez-Lazaro M., 2002. Flavonoids as anticancer agents: structure-activity relationship study. Curr. Med. Chem. Anticancer Agents 2, 691-714.

5. Magadula J.J., 2014. Phytochemistry and pharmacology of the genus Macaranga: A review. J Med. Plant Res. 8, 489-503.

6. $\quad$ Nhiem N.X., Tai B.H., Quang T.H., Kiem P.V., Minh C.V., Nam N.H., Kim J.H., Im L.R., Lee Y.M., Kim Y.H., 2011. A new ursane-type triterpenoid glycoside from Centella asiatica leaves modulates the production of nitric oxide and secretion of TNF-a in activated RAW 264.7 cells. Bioorg. Med. Chem. Lett. 21, 1777-1781.

7. Niwa M., He Y.-H., Dou D.-Q., Terashima K., Takaya Y., 2004. Two lignan glycosides from Vitis thunbergii. Heterocycles 63, 871-877.

8. Nomura T., Zeng L., Fukai T., Zhang R.-Y., Lou Z.-C., 1992. Four new prenylated flavonoids, glyasperins A, B, C, and D from the roots of Glycyrrhiza aspera. Heterocycles $34,575-587$.

9. Thu V.K., Thang N.V., Nhiem N.X., Tai B.H., Nam N.H., Kiem P.V., Minh C.V., Anh H.L.T., Kim N., Park S., Kim S.H., 2015. Oleanane-type saponins from Glochidion glomerulatum and their cytotoxic activities. Phytochemistry 116, 213-220.

10. Yang D.-S., Peng W.-B., Yang Y.-P., Liu K.-C., Li X.-L., Xiao W.-L., 2015a. Cytotoxic prenylated flavonoids from Macaranga indica. Fitoterapia 103, 187-191.

11. Yang D.-S., Wang S.-M., Peng W.-B., Yang Y.-P., Liu K.-C., Li X.-L., Xiao W.-L., 2015b. Minor prenylated flavonoids from the twigs of Macaranga adenantha and their cytotoxic activity. Nat. Prod. Bioprospect. 5, 105-109. 
Figure 1. Chemical structures of compounds 1-11.<smiles>CC(F)(F)C=Cc1c(O)cc2oc(-c3ccc(O)c(C=O)c3)c(O)c(=O)c2c1O</smiles><smiles>CC1(C)C=Cc2cc(-c3oc4c([I-]C=C(F)F)c(O)cc(O)c4c(=O)c3O)ccc2O1</smiles><smiles>CC(C)=CCc1c(O)cc2oc(-c3ccc4c(c3)C=CC(C)(C)O4)c(O)c(=O)c2c1O</smiles><smiles>CC(C)=CCc1cc(-c2oc3cc(O)c(CC=C(C)C)c(O)c3c(=O)c2O)ccc1O</smiles><smiles>[X]c1cc(-c2oc3cc(O)cc(O)c3c(=O)c2O)ccc1O</smiles><smiles>[R]c1cc([C@H]2c3c(cc(OC)c([R20])c3[R])C[C@H](CO)[C@H]2CO)cc(OC)c1O</smiles>
Glc<smiles>[3H]C(O)OCC(CO)(CO)CO</smiles> 
Figure 2. The key HMBC correlations of compounds 1-3.
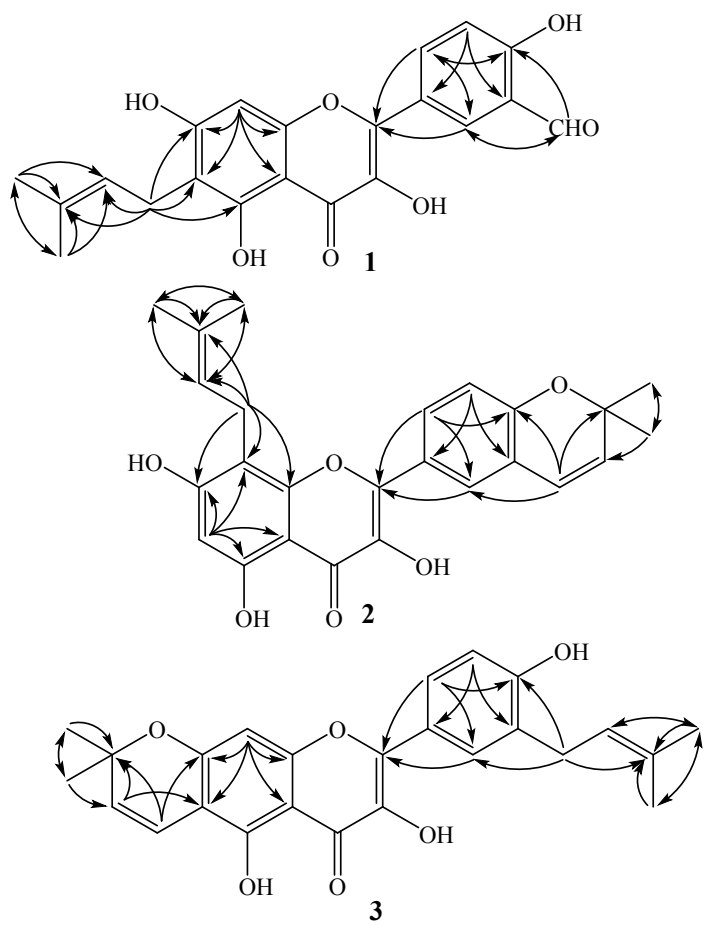
Table 1. ${ }^{1} \mathrm{H}$ - and ${ }^{13} \mathrm{C}-\mathrm{NMR}$ spectroscopic data for compounds $\mathbf{1}-\mathbf{3}$ in DMSO- $\mathrm{d}_{6}$.

\begin{tabular}{|c|c|c|c|c|c|c|}
\hline \multirow[t]{2}{*}{$\mathbf{C}$} & \multicolumn{2}{|r|}{1} & \multicolumn{2}{|r|}{2} & \multicolumn{2}{|r|}{3} \\
\hline & $\boldsymbol{\delta}_{\mathrm{C}}$ & $\delta_{\mathrm{H}}($ mult., $J$ in $\mathrm{Hz})$ & $\boldsymbol{\delta}_{\mathrm{C}}$ & $\delta_{\mathrm{H}}($ mult., $\boldsymbol{J}$ in $\mathrm{Hz})$ & $\boldsymbol{\delta}_{\mathrm{C}}$ & $\delta_{\mathrm{H}}(\mathrm{mult} ., \boldsymbol{J}$ in $\mathrm{Hz})$ \\
\hline 2 & 145.0 & - & 146.0 & - & 147.5 & - \\
\hline 3 & 136.2 & - & 135.9 & - & 135.7 & - \\
\hline 4 & 175.9 & - & 176.1 & - & 175.9 & - \\
\hline 5 & 157.4 & - & 158.2 & - & 154.6 & - \\
\hline 6 & 110.3 & - & 97.8 & $6.30(\mathrm{~s})$ & 103.9 & - \\
\hline 7 & 161.7 & - & 161.2 & - & 158.3 & - \\
\hline 8 & 92.7 & $6.50(\mathrm{~s})$ & 105.6 & - & 94.5 & $6.51(\mathrm{~s})$ \\
\hline 9 & 154.0 & - & 153.4 & - & 155.1 & - \\
\hline 10 & 102.8 & - & 103.0 & - & 103.9 & - \\
\hline $1^{\prime}$ & 122.3 & - & 123.7 & - & 121.4 & - \\
\hline $2^{\prime}$ & 128.3 & $8.50(\mathrm{~d}, 2.0)$ & 125.6 & $7.85(\mathrm{~d}, 2.5)$ & 129.2 & $7.93(\mathrm{~d}, 2.0)$ \\
\hline $3^{\prime}$ & 122.3 & - & 120.6 & - & 127.7 & - \\
\hline $4^{\prime}$ & 161.8 & - & 153.9 & - & 157.0 & - \\
\hline $5^{\prime}$ & 117.7 & $7.18(\mathrm{~d}, 9.0)$ & 116.0 & $6.92(\mathrm{~d}, 9.0)$ & 114.8 & $6.94(\mathrm{~d}, 8.5)$ \\
\hline $6^{\prime}$ & 134.9 & $8.29(\mathrm{dd}, 2.0,9.0)$ & 128.8 & $7.93(\mathrm{dd}, 2.5,9.0)$ & 128.8 & $7.88(\mathrm{dd}, 2.0,8.5)$ \\
\hline $1^{\prime \prime}$ & 20.9 & $3.24(\mathrm{~d}, 7.0)$ & 21.1 & $3.43(\mathrm{~d}, 6.5)$ & 114.5 & $6.61(\mathrm{~d}, 10.0)$ \\
\hline $2^{\prime \prime}$ & 122.1 & $5.19(\mathrm{t}, 7.0)$ & 122.5 & $5.17(t, 6.5)$ & 128.8 & $5.79(\mathrm{~d}, 10.0)$ \\
\hline $3^{\prime \prime}$ & 130.6 & - & 130.9 & - & 77.8 & - \\
\hline $4^{\prime \prime}$ & 25.4 & $1.63(\mathrm{~s})$ & 25.3 & $1.62(\mathrm{~s})$ & 27.8 & $1.43(\mathrm{~s})$ \\
\hline $5^{\prime \prime}$ & 17.6 & $1.73(\mathrm{~s})$ & 17.8 & $1.74(\mathrm{~s})$ & 27.8 & $1.43(\mathrm{~s})$ \\
\hline $6^{\prime \prime}$ & 190.5 & $10.35(\mathrm{~s})$ & 121.2 & $6.46(\mathrm{~d}, 10.0)$ & 28.1 & $3.28(\mathrm{~d}, 7.5)$ \\
\hline $7^{\prime \prime}$ & & & 131.8 & $5.85(\mathrm{~d}, 10.0)$ & 122.3 & $5.30(\mathrm{t}, 7.5)$ \\
\hline $8^{\prime \prime}$ & & & 77.0 & - & 131.7 & - \\
\hline $9^{\prime \prime}$ & & & 27.8 & $1.42(\mathrm{~s})$ & 25.4 & $1.70(\mathrm{~s})$ \\
\hline $10^{\prime \prime}$ & & & 27.8 & $1.42(\mathrm{~s})$ & 17.6 & $1.70(\mathrm{~s})$ \\
\hline
\end{tabular}


Table 2. Cytotoxic effects of compounds 1-11

\begin{tabular}{ccccc}
\hline Compounds & \multicolumn{4}{c}{ IC $\left._{\mathbf{5 0}}(\boldsymbol{\mu M})^{\boldsymbol{a}}\right)$} \\
\cline { 2 - 5 } & $\mathbf{K B}$ & $\mathbf{M C F} 7$ & HepG2 & $\mathbf{L U}$ \\
\hline $\mathbf{1}$ & $47.4 \pm 2.4$ & $>100$ & $53.1 \pm 3.7$ & $>100$ \\
$\mathbf{2}$ & $11.0 \pm 1.0$ & $15.5 \pm 1.2$ & $11.9 \pm 1.3$ & $17.0 \pm 1.3$ \\
$\mathbf{3}$ & $15.0 \pm 1.7$ & $18.1 \pm 1.9$ & $17.9 \pm 1.5$ & $20.3 \pm 2.0$ \\
$\mathbf{4}$ & $32.9 \pm 2.1$ & $33.1 \pm 3.2$ & $33.1 \pm 1.5$ & $35.0 \pm 1.7$ \\
$\mathbf{5}$ & $38.2 \pm 2.4$ & $34.4 \pm 3.1$ & $30.1 \pm 4.0$ & $34.6 \pm 3.7$ \\
$\mathbf{6}$ & $>100$ & $>100$ & $>100$ & $>100$ \\
$\mathbf{7}$ & $>100$ & $>100$ & $>100$ & $>100$ \\
$\mathbf{8}$ & $>100$ & $>100$ & $>100$ & $>100$ \\
$\mathbf{9}$ & $>100$ & $>100$ & $>100$ & $>100$ \\
$\mathbf{1 0}$ & $>100$ & $>100$ & $>100$ & $>100$ \\
$\mathbf{1 1}$ & $>100$ & $>100$ & $>100$ & $>100$ \\
$\mathbf{M X}^{\boldsymbol{b})}$ & $7.8 \pm 0.7$ & $10.3 \pm 1.1$ & $8.2 \pm 0.6$ & $7.7 \pm 0.4$ \\
\hline
\end{tabular}

a) The concentration that inhibits $50 \%$ of cell growth was calculated $\left(\mathrm{IC}_{50}\right)$. Compounds were tested at a maximum concentration of $100 \mu \mathrm{M}$. Data are means of three experiments.

${ }^{b)}$ Mitoxantrone (MX), an anticancer agent, was used as reference compound. 


\section{SUPPLEMENTARY MATERIAL}

\section{Cytotoxic prenylated flavonoids from the leaves of Macaranga indica}

Doan Thi Mai Huonga,c), Le Tran Nguyen Vua ${ }^{\mathrm{a}, \mathrm{c}}$, Luu The Anh ${ }^{\mathrm{b})}$, Nguyen Thi Cuc ${ }^{\mathrm{a}, \mathrm{c})}$, Nguyen Xuan Nhiem, ${ }^{\mathrm{a}, \mathrm{c}}$, Bui Huu Tai ${ }^{\mathrm{a}, \mathrm{c}}$, Phan Van Kiemª, ${ }^{\mathrm{a}, \mathrm{c}}$, Marc Litaudon ${ }^{\mathrm{d})}$, Tran Dang Thach), Chau Van Minha), and Pham Van Cuong a,c*

a) Advanced Center for Bioorganic Chemistry, Institute of Marine Biochemistry (IMBC), Vietnam Academy of Science and Technology (VAST), 18 Hoang Quoc Viet, Cau Giay, Hanoi, Vietnam

${ }^{b)}$ Central Institute for Natural Resources and Environmental Studies, Vietnam National National University, Hanoi, 19 Le Thanh Tong, Hoan Kiem, Hanoi, Vietnam

${ }^{c}$ Graduate University of Science and Technology, VAST, 18 Hoang Quoc Viet, Caugiay, Hanoi, Vietnam

d)Institut de Chimie des Substances Naturelles, CNRS-ICSN, UPR 2301,_Université Paris-Saclay, 91198, Gif-sur-Yvette, France

e) Institute of Applied Science and Technology, University Industry Vinh, Vinh, Vietnam

Corresponding author

\section{Pham Van Cuong, Prof, Ph.D.}

Advanced Center for Bioorganic Chemistry, Institute of Marine Biochemistry (IMBC), Vietnam Academy of Science and Technology (VAST), 18 Hoang Quoc Viet, Cau Giay, Hanoi, Vietnam E-mail address: phamvc@imbc.vast.vn 


\section{Content}

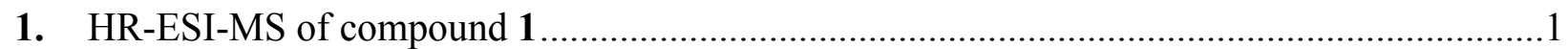

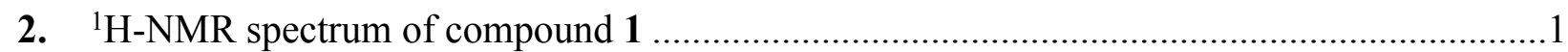

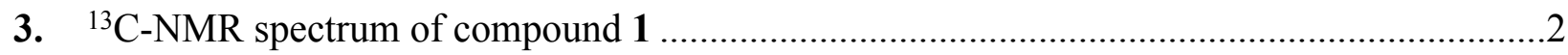

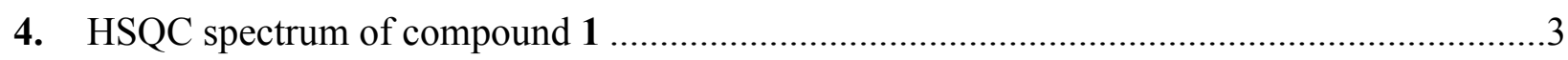

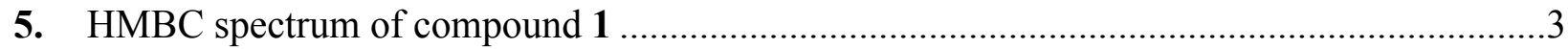

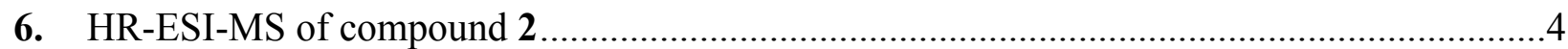

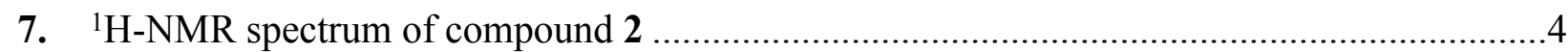

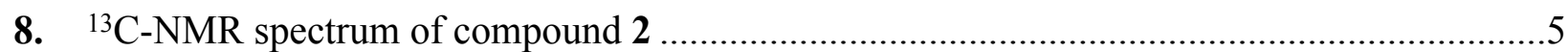

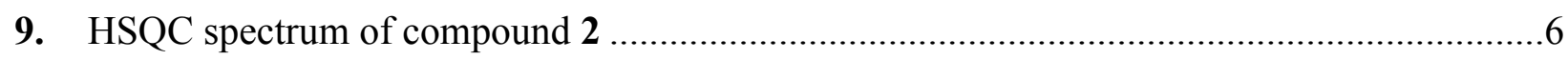

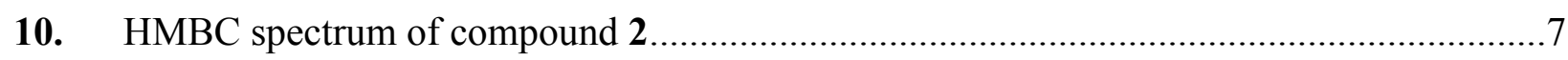

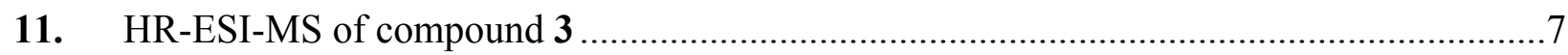

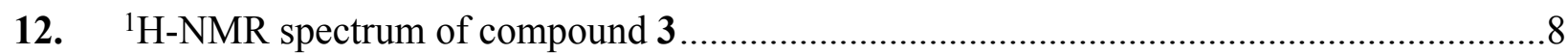

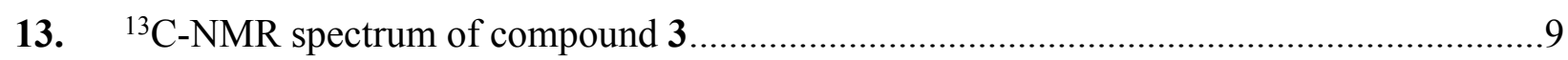

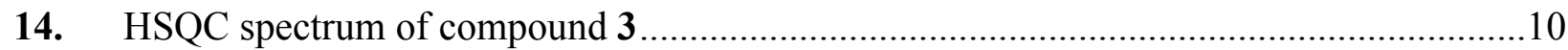

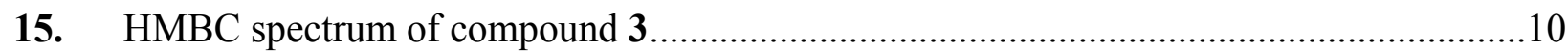


1. HR-ESI-MS of compound $\mathbf{1}$

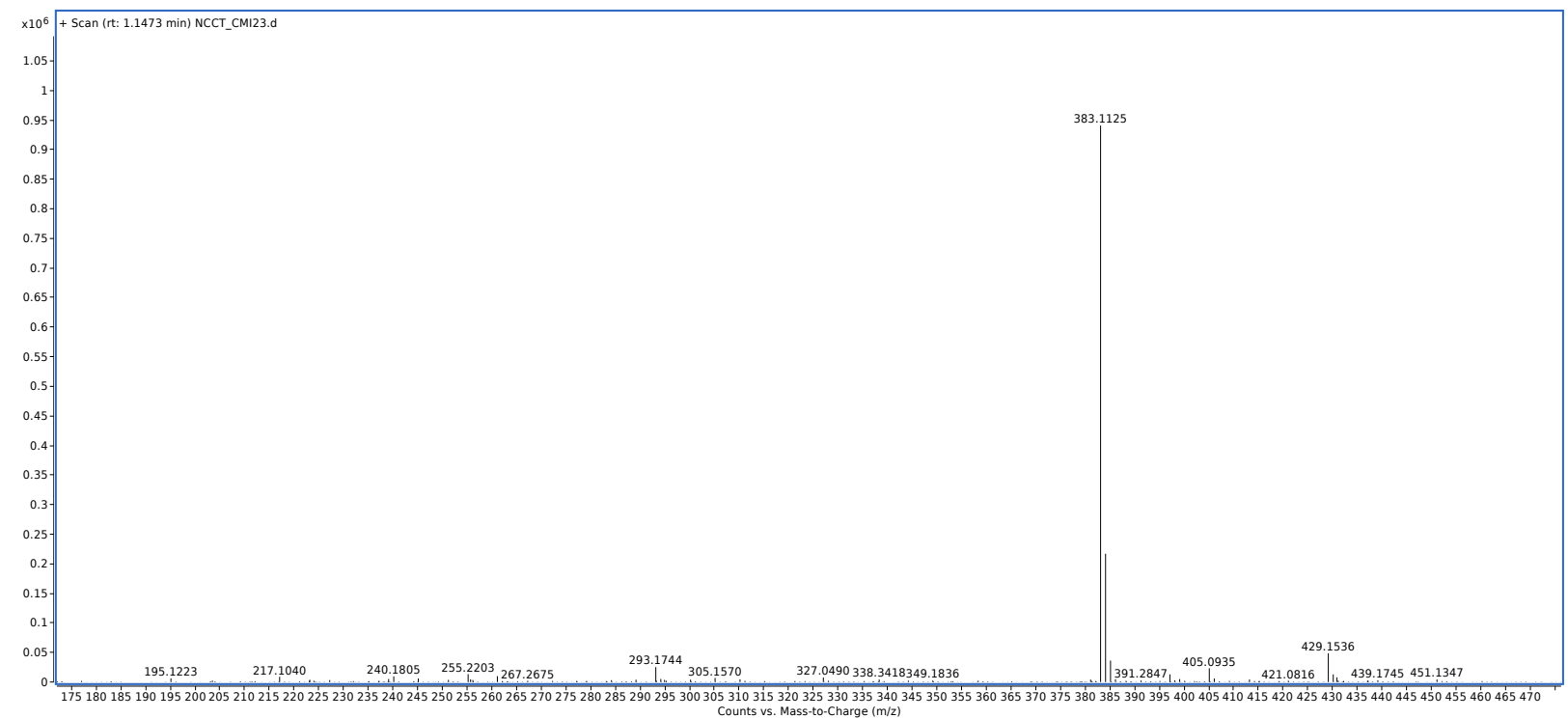

2. ${ }^{1} \mathrm{H}-\mathrm{NMR}$ spectrum of compound $\mathbf{1}$

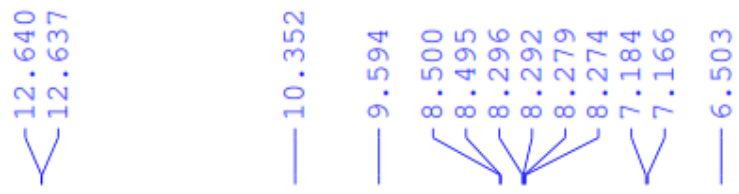

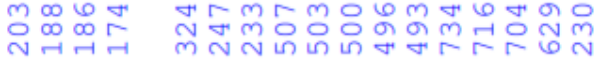

N.

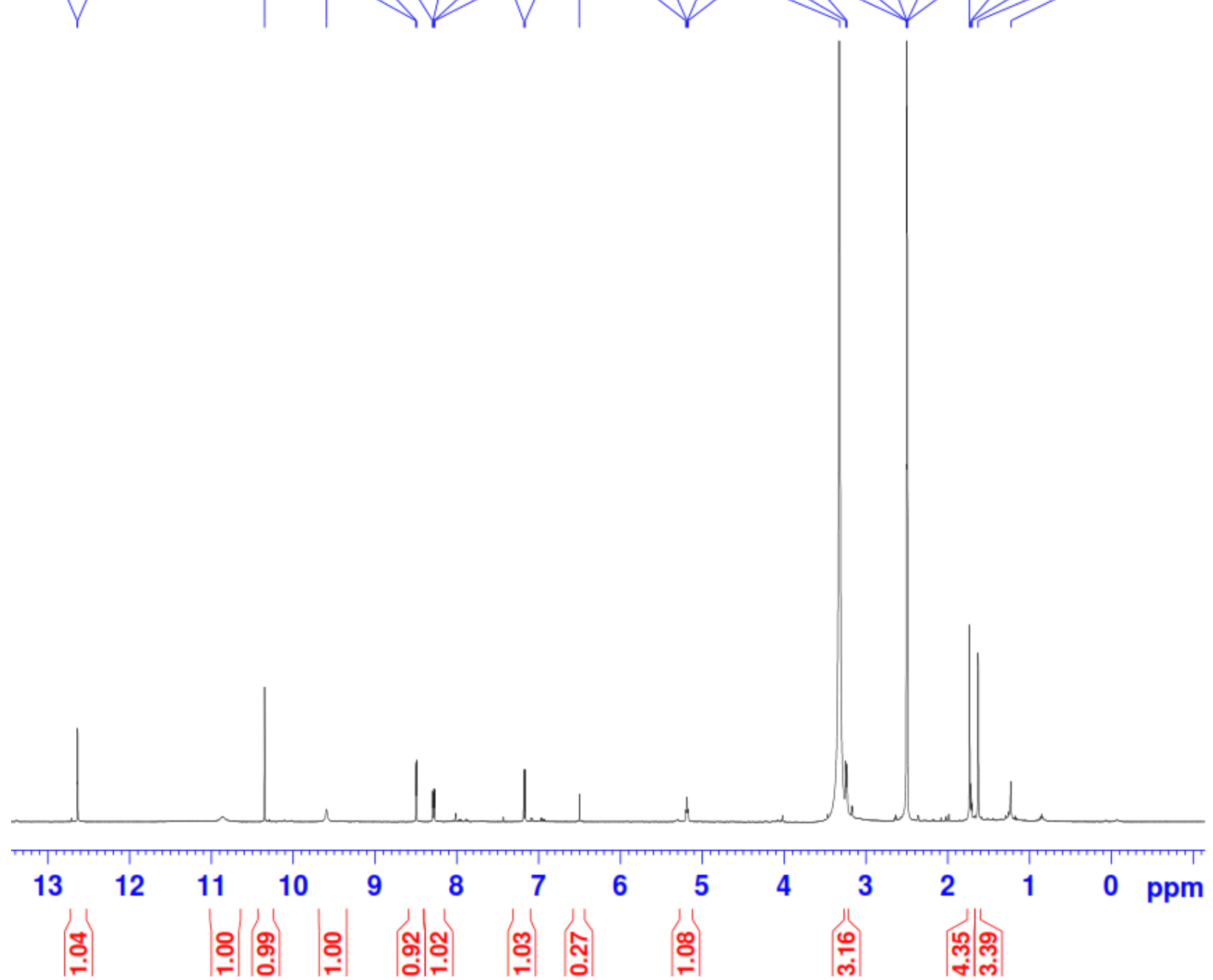


3. ${ }^{13} \mathrm{C}-\mathrm{NMR}$ spectrum of compound $\mathbf{1}$

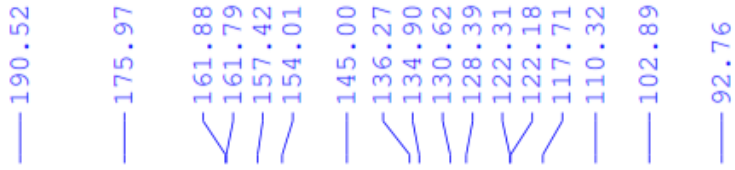

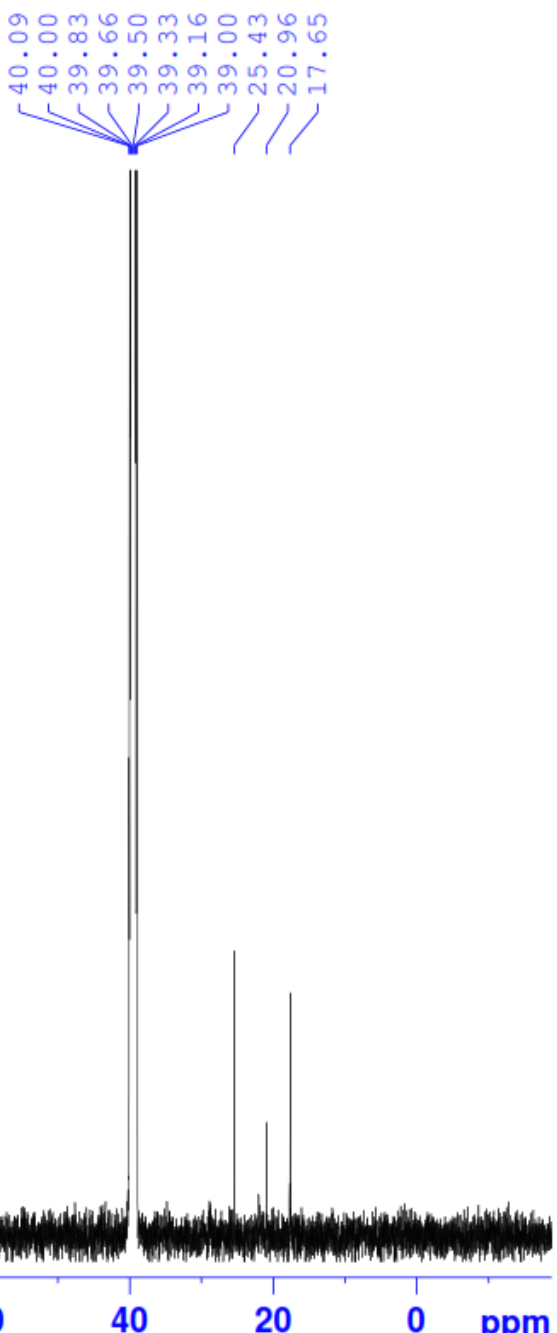


4. HSQC spectrum of compound $\mathbf{1}$

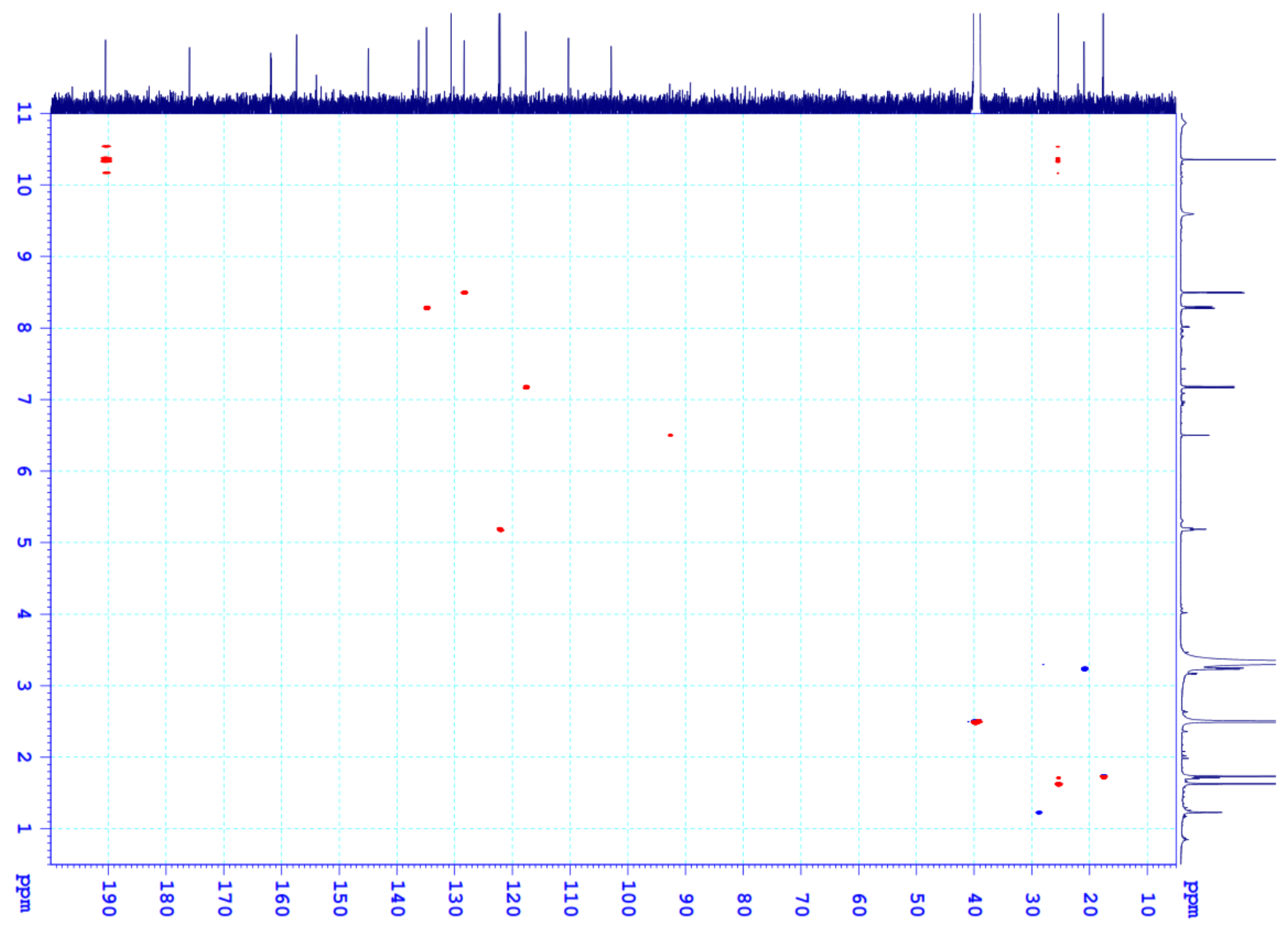

5. HMBC spectrum of compound 1

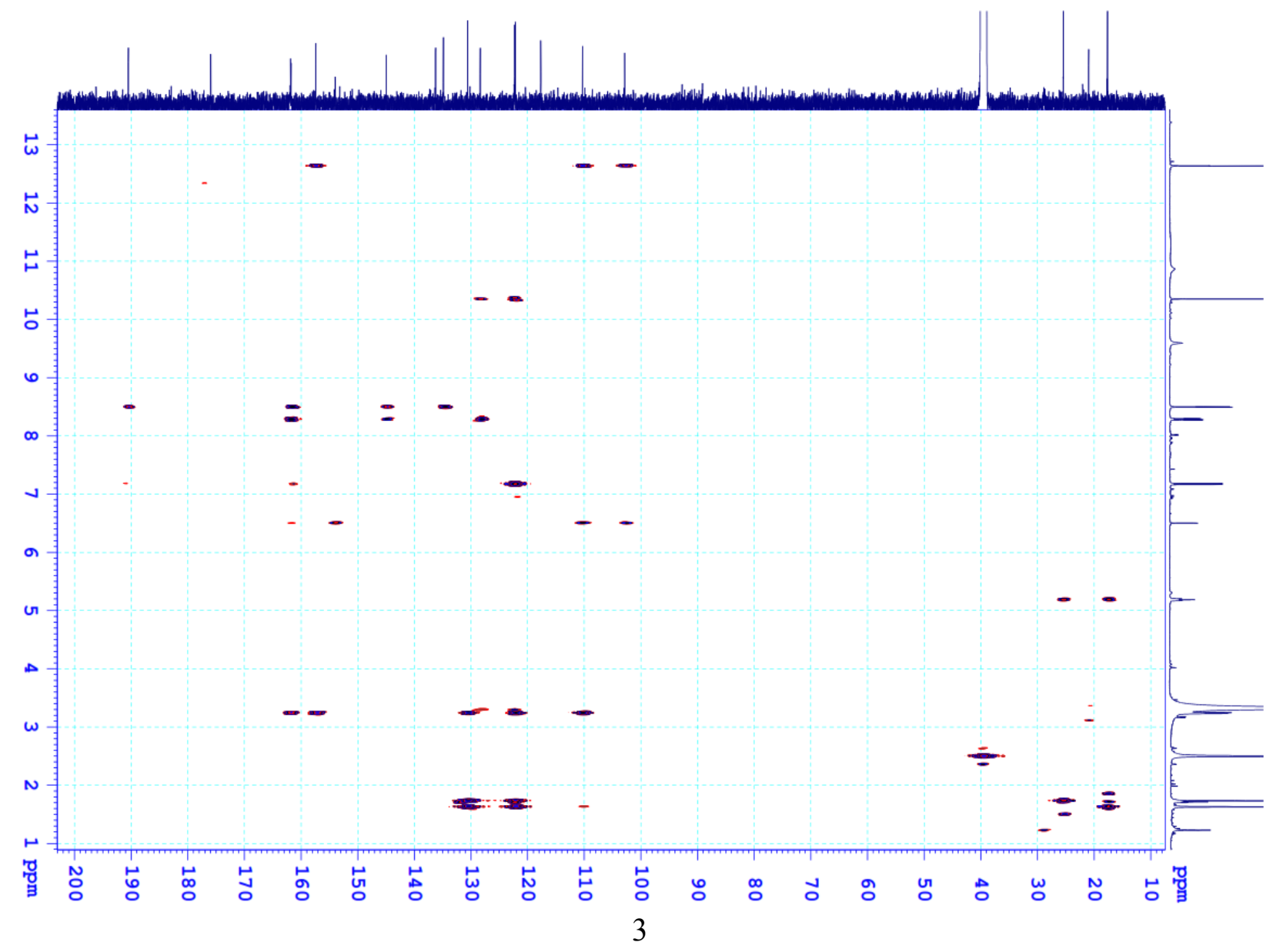


6. HR-ESI-MS of compound 2

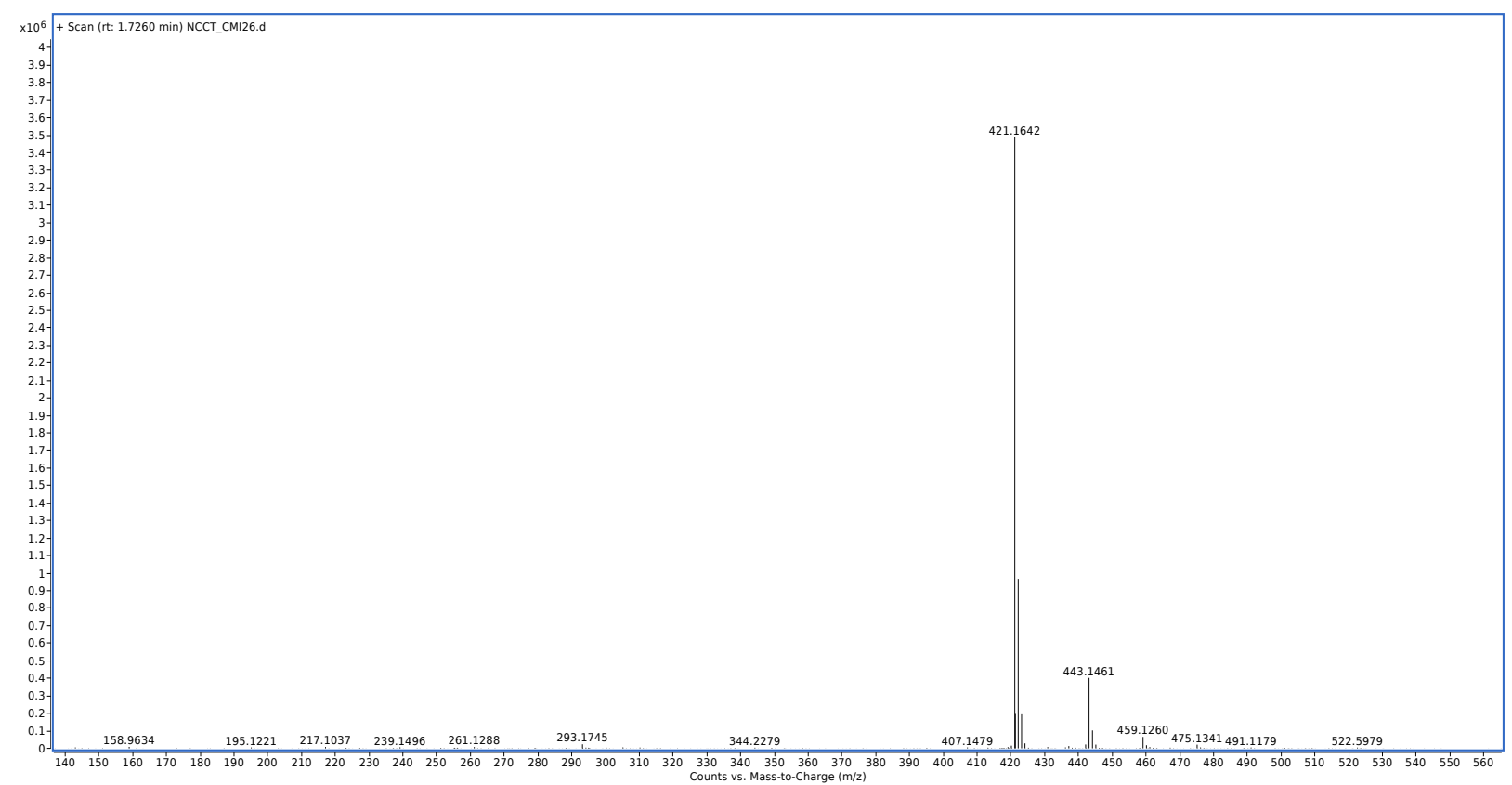

7. ${ }^{1} \mathrm{H}-\mathrm{NMR}$ spectrum of compound 2

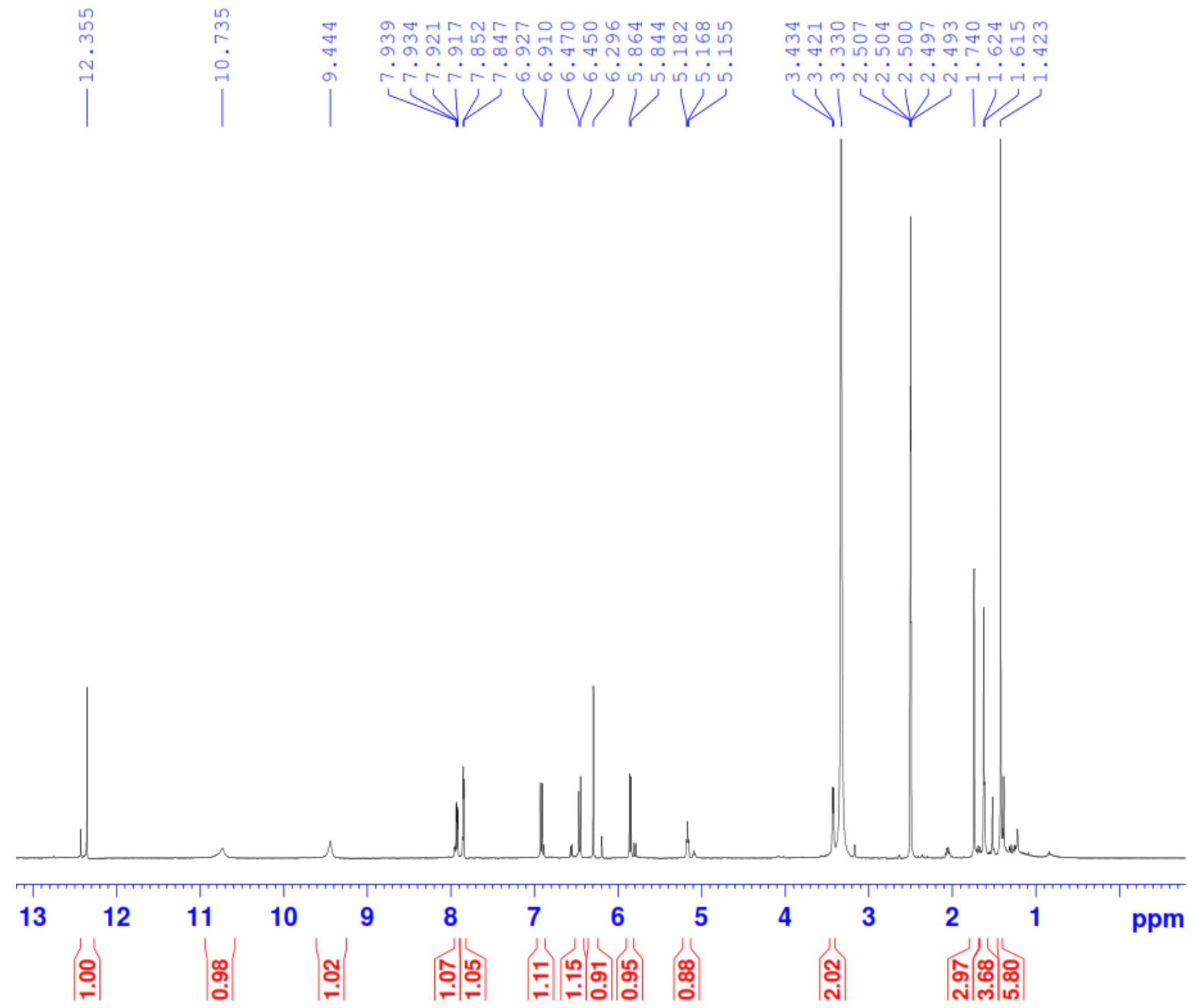


8. ${ }^{13} \mathrm{C}-\mathrm{NMR}$ spectrum of compound $\mathbf{2}$

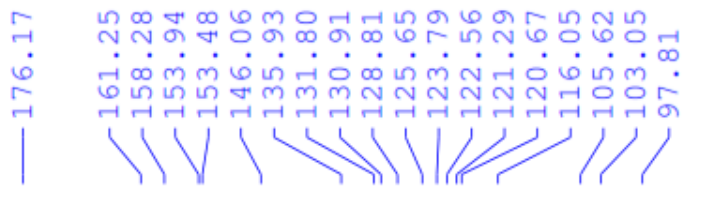

$$
\stackrel{6}{\circ}
$$

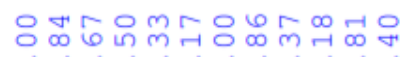

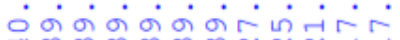
पा

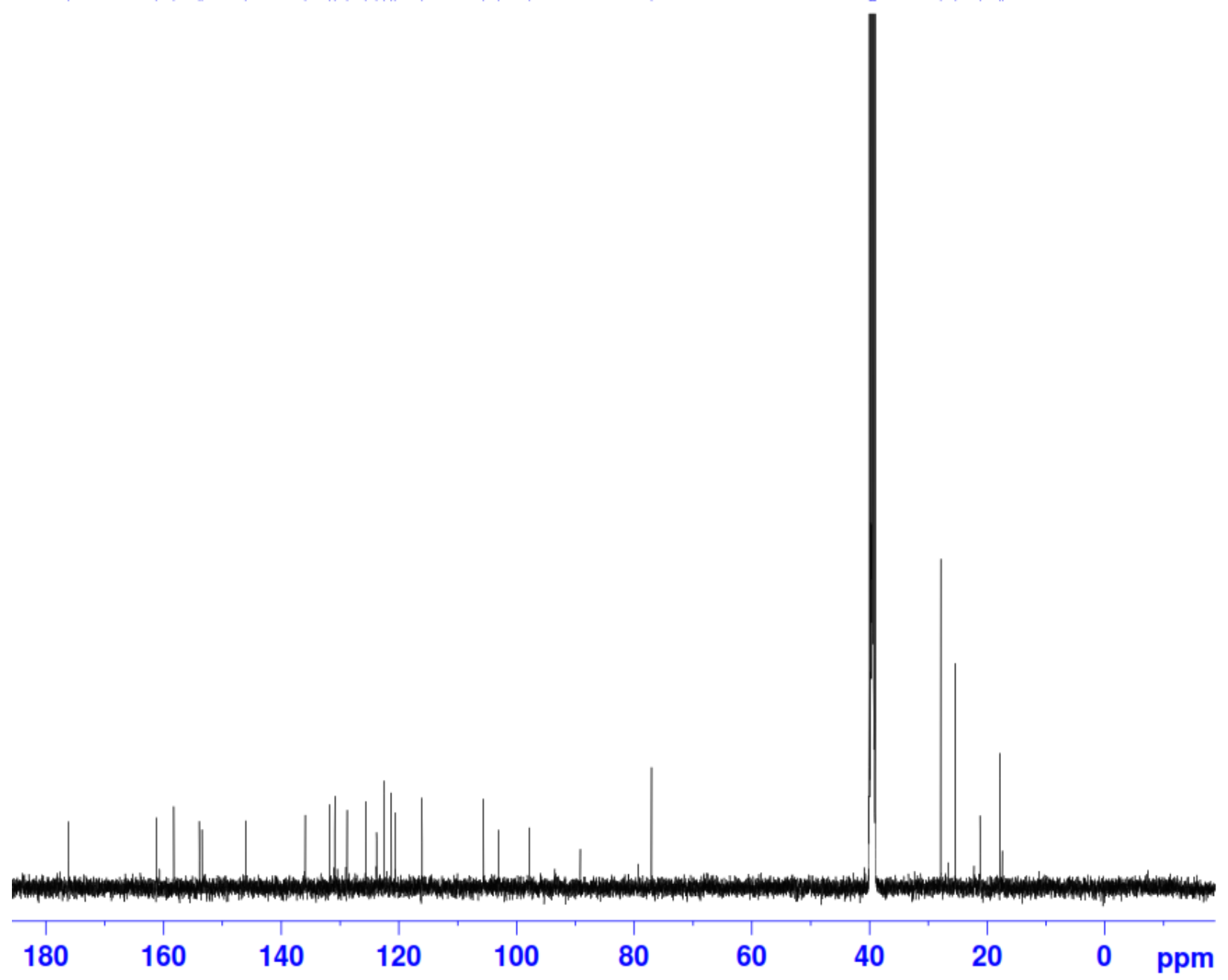


9. HSQC spectrum of compound 2

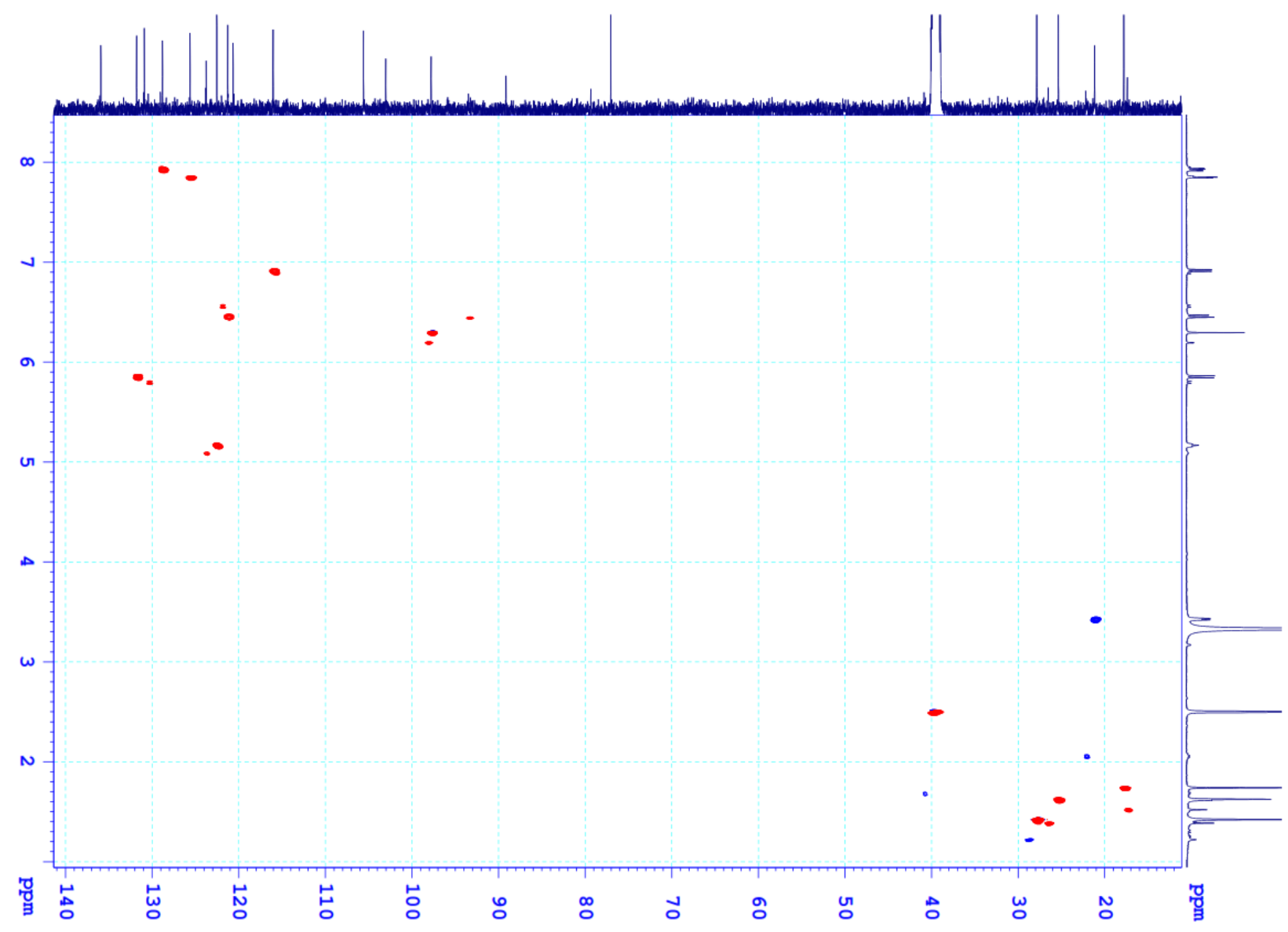


10. HMBC spectrum of compound 2

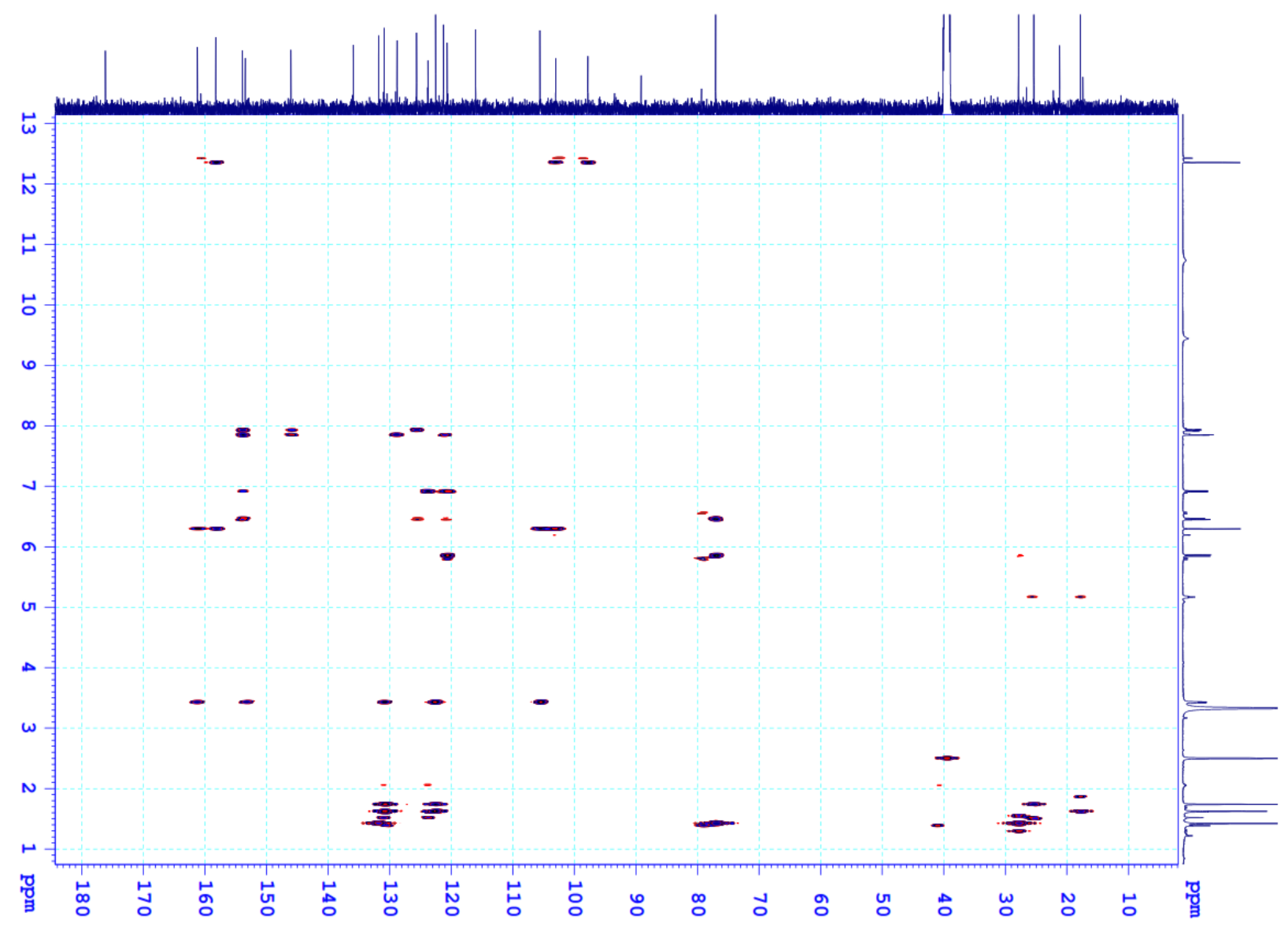

11. HR-ESI-MS of compound 3

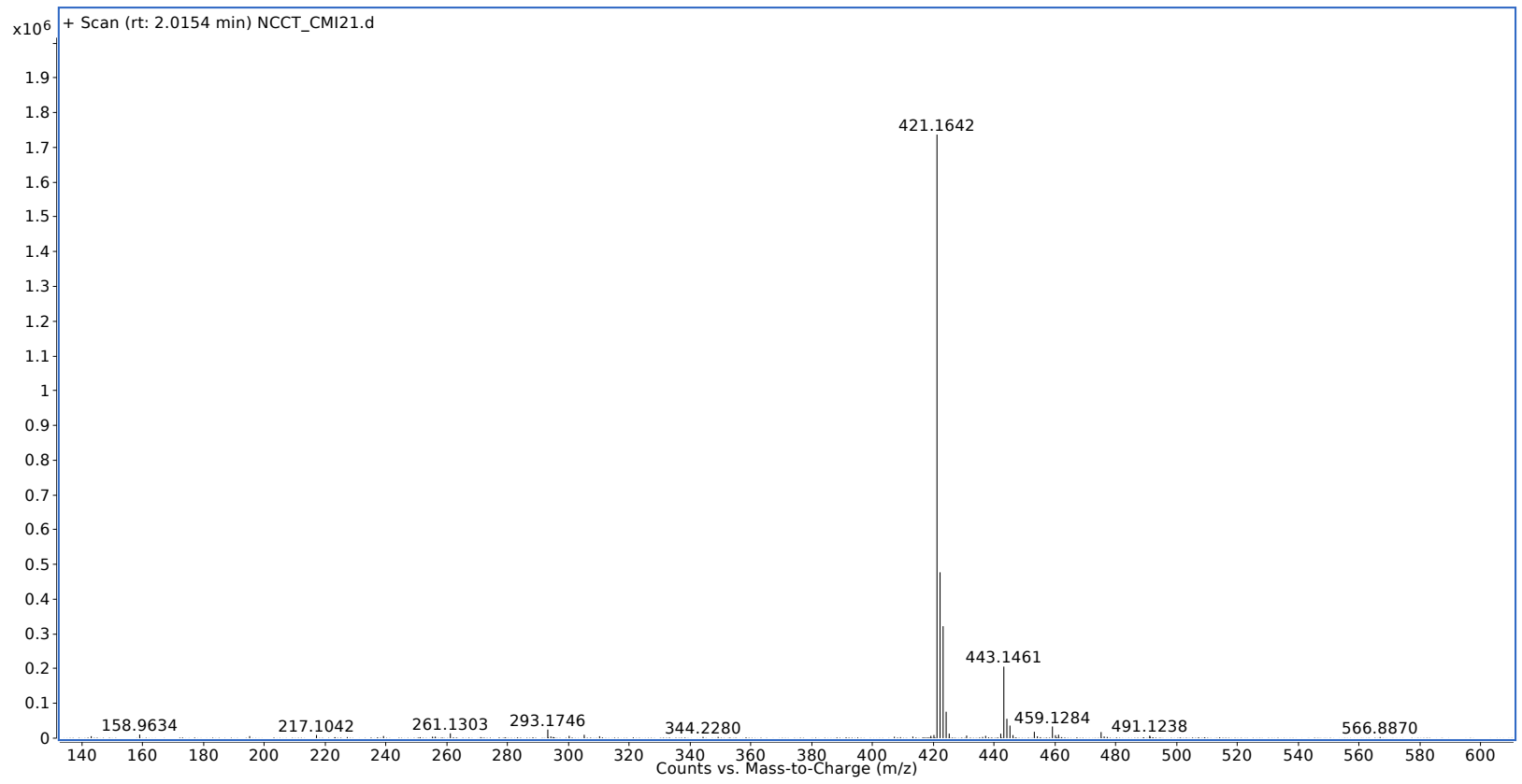


12. ${ }^{1} \mathrm{H}-\mathrm{NMR}$ spectrum of compound $\mathbf{3}$

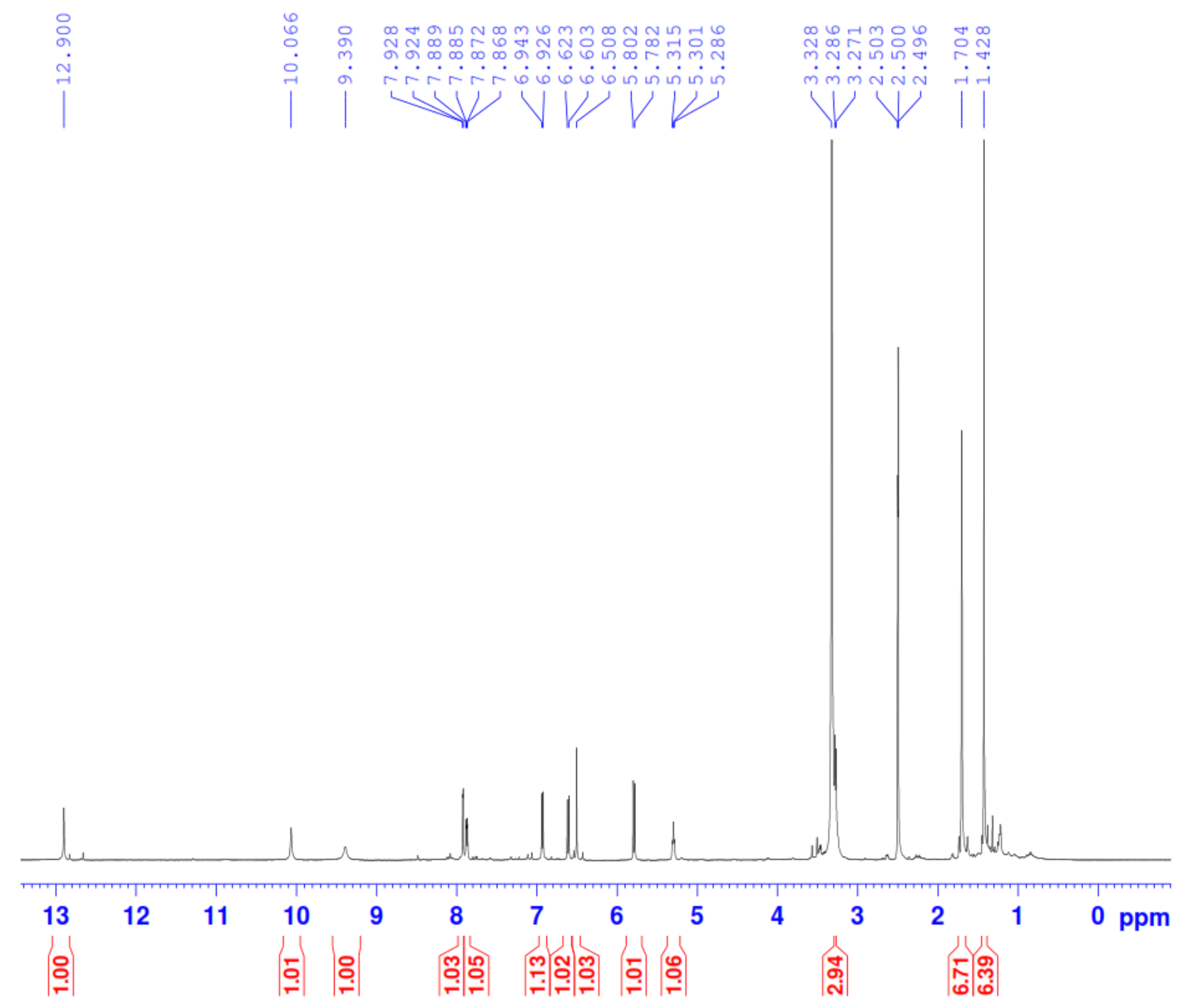


13. ${ }^{13} \mathrm{C}-\mathrm{NMR}$ spectrum of compound $\mathbf{3}$
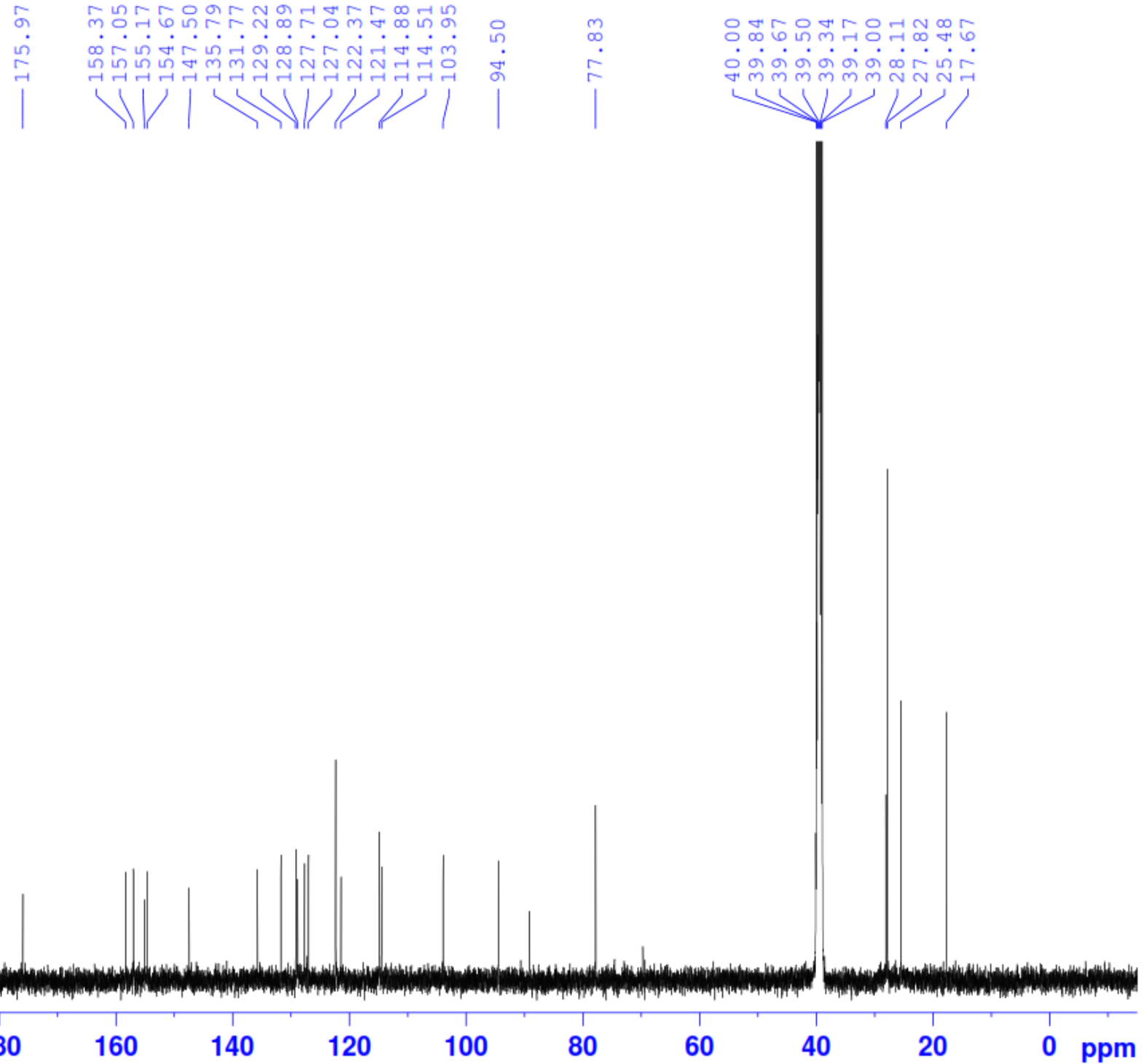
14. HSQC spectrum of compound 3

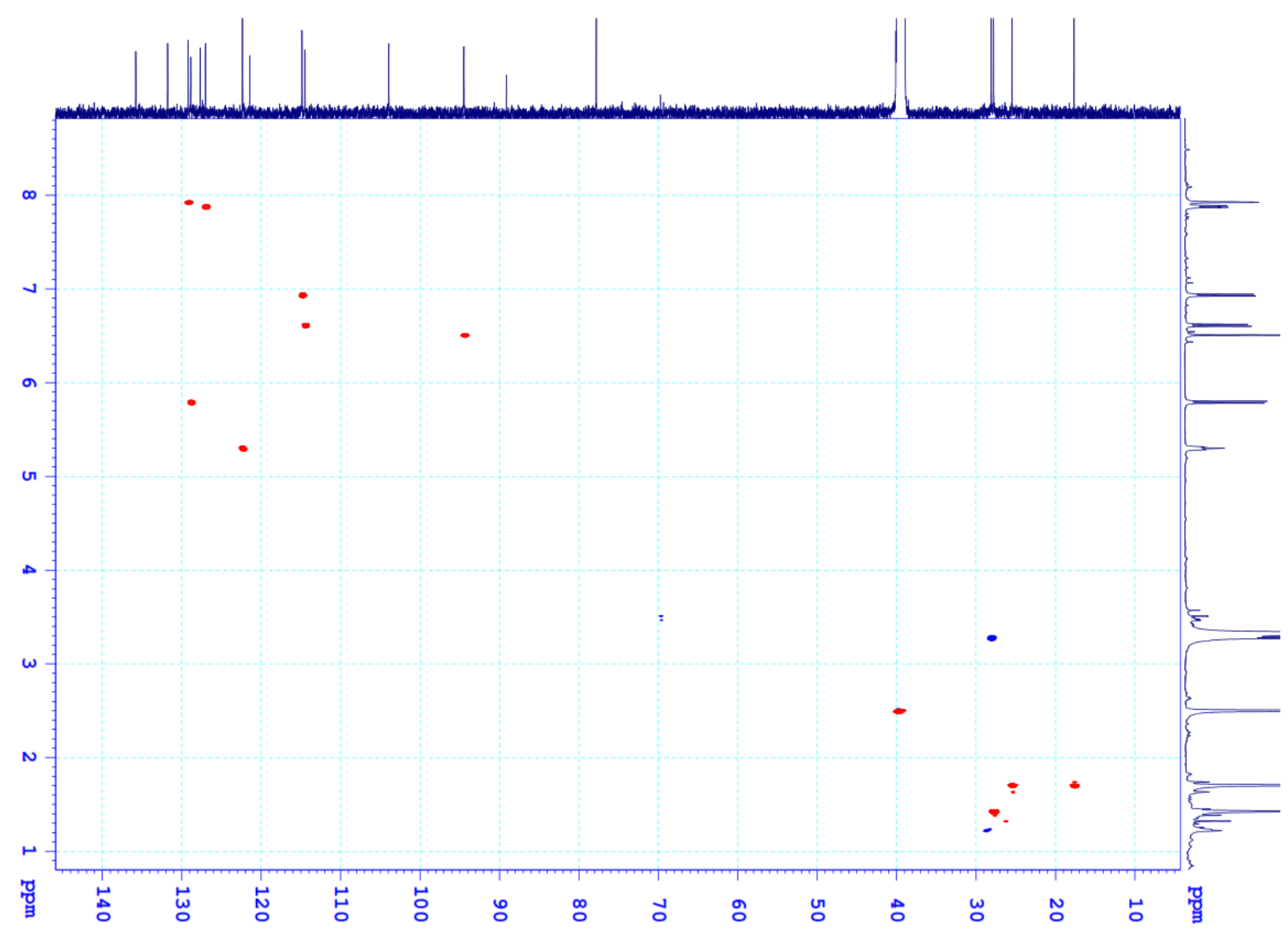

15. HMBC spectrum of compound 3

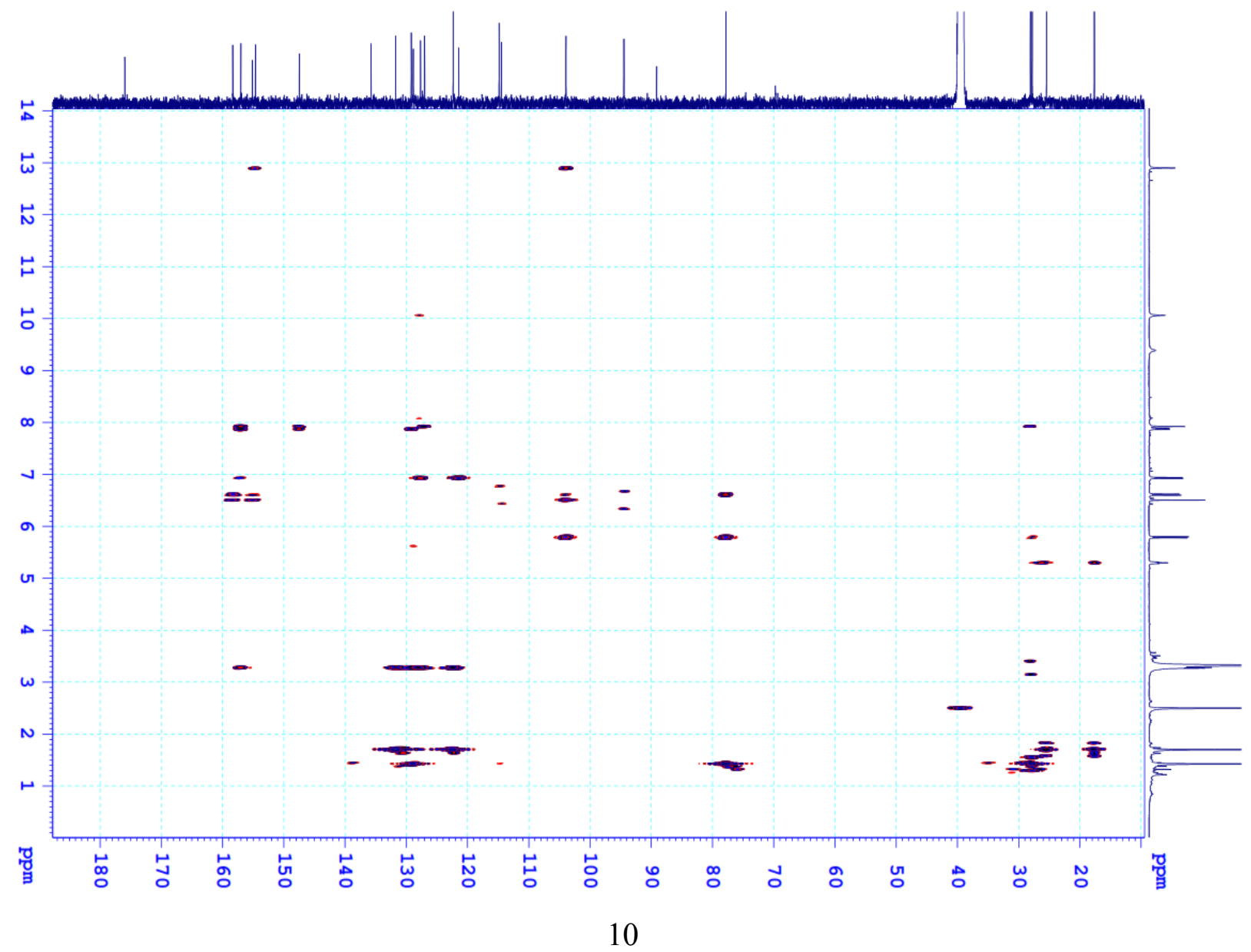

